\title{
AKIBAT HUKUM AKTA KUASA JUAL YANG DIBUAT OLEH NOTARIS YANG MEMENUHI UNSUR SENGAJA MEMBERI KESEMPATAN ATAU SARANA DALAM TINDAK PIDANA PENIPUAN (STUDI KASUS PUTUSAN PENGADILAN NEGERI NOMOR 196/Pid.B/2019/PN Dps juncto PUTUSAN PENGADILAN TINGGI NOMOR 27/Pid/2019/PT DPS)
}

\author{
Maylia Ayu Riftianti \\ Karyawan Kantor Notaris/PPAT Selam Bastomi, S.H, M.Kn. \\ mayliariftianti@gmail.com
}

\begin{abstract}
Abstrak
Penelitian ini membahas mengenai akibat hukum akta kuasa menjual yang dibuat oleh notaris yang memenuhi unsur sengaja memberi kesempatan atau sarana dalam tindak pidana penipuan dan pertanggungjawaban notaris terhadap akta yang telah dibuatnya berdasarkan studi kasus Putusan Pengadilan Negeri Nomor 196/Pid.B/2019/PN Dps juncto Putusan Pengadilan Tinggi Nomor 27/Pid/2019/PT DPS. Penelitian ini merupakan penelitian hukum yuridis normatif dengan metode kualitatif untuk menganalisa data dan tipe penelitian diskriptif analitis. Berdasarkan analisis yang dilakukan, diketahui bahwa dalam akta kuasa menjual tersebut berdiri sendiri, memuat klausul jual beli pada premis akta dan merupakan kuasa mutlak yaitu kuasa yang didalamnya mengandung unsur tidak dapat ditarik kembali oleh pemberi kuasa dan pada hakekatnya merupakan pemindahan hak atas tanah yang dilarang oleh Pasal 39 ayat (1) huruf (d) Peraturan Pemerintah Nomor 24 Tahun 1997 sehingga dapat beresiko batal demi hukum dan pertanggungjawaban notaris terhadap Akta Kuasa Menjual tersebut adalah pemberian sanksi pidana sesuai ketentuan Kitab Undang-Undang Hukum Pidana dengan diikuti pemberian sanksi administratif sesuai ketentuan Undang-Undang Jabatan Notaris.
\end{abstract}

Kata kunci : Akibat Hukum, Akta Kuasa Menjual, Kuasa Mutlak

\begin{abstract}
This research discusses the legal consequences of a power of attorney to sell made by a notary that fulfills the element of intentionally providing an opportunity or means in the crime of fraud and the accountability of the notary to the deed he has made based on a case study of District Court Decision Number 196 / Pid.B / 2019 / PN Dps juncto High Court Decision Number 27 / Pid / 2019 / PT DPS. This research is a normative legal research with qualitative methods to analyze data and analytical descriptive research types. Based on the analysis, it is known that the deed of selling power is independent, contains a sale and purchase clause on the premise of the deed and is an absolute power of attorney, namely power which contains elements that cannot be withdrawn by the power of attorney and are essentially a transfer of rights to land that is prohibited by Article 39 subsection (1) letter (d) Government Regulations Number 24 of 1997 so that it can be at risk of being null and void by law and the notary liability of the Selling Power of Attorney is the provision of criminal sanctions in accordance with the provisions of the Criminal Law Act followed by administrative sanctions in accordance with the provisions of the Law of Notary Position.
\end{abstract}

Keywords: Legal Consequences, Power of Attorney to Sell, Absolute Power 


\section{PENDAHULUAN}

Secara kodrati, manusia merupakan makhluk monodualistis, artinya selain sebagai makhluk individu, manusia juga berperan sebagai makhluk sosial. ${ }^{1}$ Kehidupan manusia adalah suatu dinamika yang memadukan manusia dengan sesamanya dan dengan lingkungannya. ${ }^{2}$ Hubungan antara individu-individu yang merupakan subyek hukum maupun antar badan hukum seringkali merupakan suatu hubungan hukum yang tentu dapat dikategorikan sebagai suatu perbuatan hukum. ${ }^{3}$ Perbuatan hukum mengakibatkan timbulnya hak dan kewajiban diantara para pihak. Bahwa untuk menjamin kepastian, ketertiban, dan perlindungan hukum mengenai perbuatan, perjanjian, penetapan, dan peristiwa hukum dibutuhkan alat bukti tertulis yang bersifat autentik yang dibuat di hadapan atau oleh Notaris.

Berdasarkan Undang-Undang Republik Indonesia Nomor 2 Tahun 2014 Tentang Perubahan Atas Undang-Undang Nomor 30 Tahun 2004 Tentang Jabatan Notaris Tambahan Lembaran Negara Republik Indonesia Nomor 5491 (untuk selanjutnya disebut UUJN), Notaris adalah pejabat umum yang berwenang untuk membuat akta autentik dan memiliki kewenangan lainnya sebagaimana dimaksud dalam Undang-Undang ini atau berdasarkan undang-undang lainnya. Kewenangan Notaris berdasarkan Pasal 15 UUJN menyatakan bahwa Notaris berwenang membuat akta autentik mengenai semua perbuatan, perjanjian, dan penetapan yang diharuskan oleh peraturan perundangundangan dan/atau yang dikehendaki oleh yang berkepentingan untuk dinyatakan dalam akta autentik, menjamin kepastian tanggal pembuatan akta, menyimpan akta, memberikan grosse, salinan dan kutipan akta, semuanya itu sepanjang pembuatan akta itu tidak juga ditugaskan atau dikecualikan kepada pejabat lain atau orang lain yang ditetapkan oleh undang-undang. Selain itu, Notaris dalam jabatannya wajib memberikan konsultasi hukum kepada masyarakat. ${ }^{4}$

Salah satu kewajiban Notaris adalah menuangkan kesepakatan para pihak mengenai pembuatan akta autentik terkait peralihan hak atas tanah seiring dengan perkembangan dalam masyarakat terkait tempat tinggal dan ekonomi bisnis. Bentuk peralihan hak yang sering dilakukan dalam masyarakat adalah melalui jual beli atas tanah. Berdasarkan Pasal 37 ayat (1) Peraturan Pemerintah Republik Indonesia Nomor 24 Tahun 1997 Tentang Pendaftaran Tanah Tambahan Lembaran Negara Republik Indonesia 3696 (untuk selanjutnya disebut PP No. 24 Tahun 1997), yang selengkapnya berbunyi :

1 Aim Abdulkarim, Pendidikan Kewarganegaraan, (Bandung: Grafindo Media Pratama, 2006), hlm 2.

${ }^{2}$ Literasi publik, "Pemahaman Manusia Sebagai Makhluk Sosial", diakses dari https://www.literasipublik.com/pemahaman-manusia-sebagai-makhluk-sosial, pada tanggal 12 Maret 2020 pukul 14.59 .

${ }^{3}$ Fatmawati, "Kajian Yuridis Pembatalan Perjanjian Pengikatan Akta Jual Beli Tanah Terkait Syarat Subjektif”, Jurnal Magister Kenotariatan Fakultas Hukum Universitas Negeri Sebelas Maret Vol 6 No. 1, 2019.

${ }^{4}$ Hilda Sophia Wiradireja, "Pertanggungjawaban Pidana Notaris Dalam Pembuatan Akta Yang Didasarkan Pada Keterangan Palsu Dihubungkan Dengan Undang-Undang Nomor 30 Tahun 2004 Tentang Jabatan Notaris Jo Undang-Undang Nomor 2 Tahun 2014 dan KUHP”, Jurnal Wawasan Hukum, 2015. 
"Peralihan hak atas tanah dan hak milik atas satuan rumah susun melalui jual beli, tukar menukar, hibah pemasukan dalam perusahaan dan perbuatan hukum pemindahan hak lainnya, kecuali pemindahan hak melalui lelang hanya dapat didaftarkan jika dibuktikan dengan akta yang dibuat oleh PPAT yang berwenang menurut ketentuan peraturan perundang-unadngan yang berlaku."

Selain Pejabat Pembuat Akta Tanah (untuk selanjutnya disebut PPAT), berdasarkan Pasal 15 ayat 2 huruf (f) UUJN, Notaris juga mempunyai kewenangan dalam membuat akta autentik dalam bidang pertanahan.

Menurut Pasal 1457 KUHPerdata, jual beli adalah suatu perjanjian, dengan mana pihak yang satu mengikatkan dirinya untuk menyerahkan suatu kebendaan dan pihak yang lain untuk membayar harga yang telah dijanjikan. ${ }^{5}$ Perjanjian jual beli berdasarkan azas konsesualisme yang menjiwai hukum perikatan KUHPerdata sudah dilahirkan saat tercapainya "sepakat" mengenai barang dan harga, Pasal 1458 KUHPerdata menyebutkan : jual beli dianggap telah terjadi antara kedua belah pihak seketika setelah mereka mencapai sepakat tentang barang dan harga meskipun barang itu belum diserahkan maupun harganya belum dibayar. ${ }^{6}$

Dalam masyarakat Hukum Adat jual beli tanah dilaksanakan secara terang dan tunai. Terang berarti perbuatan hukum jual beli tersebut benar-benar dilaksanakan di hadapan Kepala Adat atau Kepala Desa. Tunai berarti adanya dua perbuatan yang dilaksanakan secara bersamaan, yaitu pemindahan hak atas tanah yang menjadi obyek jual beli dari penjual kepada pembeli dan pembayaran harga dari pembeli kepada penjual terjadi serentak dan secara bersamaan. ${ }^{7}$ Jual beli tanah berdasarkan Undang-Undang Pokok Agraria (untuk selanjutnya disebut UUPA) tidak diterangkan secara jelas, akan tetapi dalam Pasal 5 UUPA disebutkan bahwa Hukum Tanah Nasional adalah Hukum Adat. Jadi pengertian jual beli tanah menurut UUPA adalah jual beli tanah menurut hukum adat yang telah disempurnakan/dihilangkan sifat kedaerahannya. ${ }^{8}$

Jual beli dengan obyek perjanjian berupa tanah haruslah mengikuti ketentuan yang diatur dalam UUPA yang menganut asas hukum adat yakni kontan dan konkret. Tetapi dalam prakteknya, banyak pembeli yang ingin membeli tanah tersebut secara angsuran/bertahap, sehingga akta jual beli belum dapat dibuatkan oleh PPAT hingga pembeli telah melunasi tanah tersebut. Untuk memberikan kepastian hukum kepada penjual agar pembeli tidak secara sepihak membatalkan janji untuk membeli tanah tersebut, maka dibuat perjanjian pengikatan jual beli (PPJB). ${ }^{9}$ Pengikatan Jual Beli pengertiannya menurut R. Subekti dalam bukunya adalah perjanjian antar pihak penjual dan pihak pembeli sebelum dilaksanakannya jual beli dikarenakan adanya unsur-unsur

${ }^{5}$ Kitab Undang-Undang Hukum Perdata (Burgerlijk Wetboek), Diterjemahkan oleh R. Subekti dan R. Tjitrosudibio, Cet. 34, (Jakarta: Pradya Paramita, 2006), Pasal 1457.

${ }^{6}$ Wiratni Ahmadi, dkk., Teknik Pembuatan Akta Notaris, (Bandung: Logoz Publishing, 2016), hlm. 95-96.

${ }^{7}$ Effendi Perangin, Hukum Agraria Indonesia Suatu Telaah Dari Sudut Pandang Praktisi Hukum, (Jakarta: PT. Raja Grafindo Persada, 1994), hlm. 15. 2007), hlm. 76 .

${ }^{8}$ Adrian Sutedi, Peralihan Hak Atas Tanah dan Pendaftarannya, (Jakarta: Sinar Grafika,

\footnotetext{
${ }^{9}$ Wiratni Ahmadi, dkk, op.cit., hlm. 102.
} 
yang harus dipenuhi untuk jual beli tersebut antara lain sertifikat belum ada karena masih dalam proses, belum terjadi pelunasan harga. ${ }^{10}$

Pembuatan perjanjian pengikatan jual beli harus ditindaklanjuti dengan pembuatan akta jual beli, karena pada dasarnya perjanjian pengikatan jual beli belum mengalihkan hak kepemilikan hak atas tanah secara hukum. ${ }^{11}$ Pembuatan perjanjian pengikatan jual beli dalam hal sudah terjadi pelunasan biasanya dalam prakteknya diikuti dengan pembuatan akta kuasa menjual, dengan tujuan pembeli dapat mewakili penjual dalam hal penandatanganan akta jual beli dan proses balik nama apabila hal-hal yang perlu diselesaikan sudah terselesaikan.

Menurut Pasal 1792 KUHPerdata, pemberian kuasa adalah suatu perjanjian dengan mana seorang memberikan kekuasaan atau wewenang kepada seorang lain, yang menerimanya untuk atas namanya menyelenggarakan suatu urusan. Suatu urusan yang dimaksud hanya untuk perbuatan hukum. ${ }^{12}$ Pemberian kuasa ini seringkali dilakukan karena ada kalanya seseorang tidak dapat melakukan suatu perbuatan itu sendiri yang bisa saja disebabkan karena adanya benturan kepentingan pada waktu yang bersamaan, sehingga untuk mengatasi masalah-masalah tersebut, ia membutuhkan jasa orang lain untuk membantu menyelesaikan urusan tersebut. ${ }^{13}$

Dalam prakteknya, jual beli dilakukan dengan pembuatan kuasa menjual yang pada hakekatnya memindahkan hak atas tanah tanpa membuat perjanjian pengikatan jual beli terlebih dahulu. Hal yang perlu dicatat bahwa akta kuasa menjual seharusnya bukan untuk memindahkan kepemilikan hak kepada penerima kuasa, tetapi hanya mewakili pemberi kuasa selaku penjual. Dalam artinya, kepentingannya tetap atas nama penjual sebagaimana diamanatkan secara tegas dalam kuasanya. Akta kuasa menjual juga bukan kuasa untuk mencari pembeli (memasarkan/menjualkan), melainkan kuasa untuk mewakili penjual dalam suatu transaksi jual beli, dimana para pihak, obyek dan harganya sudah disepakati sebelumnya. ${ }^{14}$ Berdasarkan Instruksi Menteri Dalam Negeri Nomor 14 Tahun 1982 tentang Larangan Penggunaan Kuasa Mutlak Sebagai Pemindahan Hak Atas Tanah menjelaskan bahwa:

a. Kuasa Mutlak adalah kuasa yang di dalamnya mengandung unsur tidak dapat ditarik kembali oleh pemberi kuasa;

b. Kuasa Mutlak merupakan pemindahan hak atas tanah yang memberikan kewenangan kepada penerima kuasa untuk menguasai dan menggunakan

${ }^{10}$ R. Subekti, Hukum Perjanjian, (Jakarta: Internasa, 1979), hlm. 75.

${ }^{11}$ Nur Dwitya Pradita, "Perbuatan Notaris Yang Melakukan Peralihan Hak Atas Tanah Menggunakan Kuasa Jual Yang Perjanjian Pengikatan Jual Belinya Belum Lunas (Studi Kasus Putusan Pengadilan Negeri Nomor 120/PDT.G/2018/PN.TGN Dan Putusan Majelis Pemeriksa Pusat Notaris Nomor 08/B/MPPN/XI/2018)”, Jurnal Universitas Indonesia, 2019.

${ }^{12}$ Leny Kurniawati, “Akta Perjanjian Pengikatan Jual Beli Dan Kuasa Menjual Sebagai Bentuk Perlindungan Hukum Terhadap Pembeli Hak Atas Tanah", Jurnal Hukum dan Kenotariatan Volume 2 Nomor 1 Februari 2018.

${ }^{13}$ Clara Vania dan Gunawan Djajaputra, "Keabsahan Penggunaan Kuasa Mutlak Dalam Perjanjian Pengikatan Jual Beli (PPJB) Tanah Yang Dibuat Oleh Notaris”. Jurnal Hukum Adigama, 2018.

${ }^{14}$ Bhakti Simamora, “Akta Kuasa Menjual Tanah/Bangunan”, diakses dari http://notarisbhakti-simamora.blogspot.com/2017/03/akta-kuasa-menjual-tanah-dan-bangunan.html, pada tanggal 3 Maret 2020 pukul 10.42 . 
tanahnya serta melakukan segala perbuatan hukum yang menurut hukum dapat dilakukan oleh pemegang haknya. ${ }^{15}$

Penggunaan surat kuasa mutlak dilarang digunakan dalam proses pemindahan hak atas tanah/jual beli tanah, maksud dan larangan tersebut untuk menghindari penyalahgunaan hukum yang mengatur pemberian kuasa dengan mengadakan pemindahan hak atas tanah secara terselubung dengan menggunakan bentuk "kuasa mutlak".

Bahwa sehubungan dengan adanya niat yang tidak baik oleh para pihak terkait pembuatan akta kuasa menjual misalnya terdapat unsur penipuan pada pihak lainnya, atau bahkan Notaris dalam menjalankan tugas dan jabatannya dalam membuat akta melakukan kesalahan atau kekeliruan yang disebabkan perilaku tidak profesional serta memihak pada salah satu pihak sehingga terjadi permasalahan terhadap akta yang dibuatnya, mengakibatkan Notaris dapat terindikasi tindak pidana dalam pembuatan akta autentik. Oleh karenanya dalam hal menuangkan kesepakatan para pihak ke dalam bentuk akta autentik khususnya terkait akta kuasa menjual tersebut harus dilaksanakan dengan kehatihatian, sebagaimana dinyatakan dalam Pasal 16 ayat 1 huruf a UUJN menyebutkan bahwa kewajiban Notaris dalam menjalankan jabatannya, Notaris wajib bertindak amanah, jujur, seksama, mandiri, tidak berpihak dan menjadi kepentingan pihak terkait dalam perbuatan hukum. ${ }^{16}$

Pembuatan akta kuasa mutlak untuk menjual yang pada hakekatnya merupakan pemindahan hak atas tanah terjadi dalam praktek, yang mana dasar kepemilikan penjual dalam pembuatan akta kuasa menjual tersebut masih berupa perjanjian pengikatan jual beli dan adanya unsur penipuan dari salah satu pihak, menyebabkan notaris terjerat tindak pidana dikarenakan salah satu faktornya, Notaris tidak menerapkan prinsip kehati-hatian dalam pembuatan akta tersebut. Salah satu kasus pembuatan akta kuasa menjual tersebut yaitu kasus dalam Putusan Perk. Pidana Nomor 196/Pid.B/2019/PN Dps juncto Putusan Nomor 27/Pid/2019/PT DPS (untuk selanjutnya disebut Putusan Pidana), Notaris di Kabupaten Badung telah di dakwa "sengaja memberi kesempatan atau sarana dalam tindak pidana penipuan" sehubungan dengan pembuatan akta kuasa menjual yang didasarkan pada perjanjian pengikatan jual beli dan ternyata dalam fakta persidangan akta perjanjian pengikatan jual beli yang menjadi dasar pembuatan akta kuasa menjual tersebut sudah dibatalkan oleh para pihak di notaris lain. Bahwa berdasarkan fakta-fakta hukum, Notaris tersebut terbukti melanggar Pasal 378 jo Pasal 56 ayat 2 Kitab UndangUndang Hukum Pidana (untuk selanjutnya disebut KUHP).

Ketertarikan Penulis terhadap penelitian ini adalah bahwa dalam Putusan Pidana tersebut hanya memberikan putusan terhadap subyek hukum yaitu Notaris yang membuat akta Kuasa Menjual yang terbukti sengaja melakukan tindak pidana sesuai dakwaan Penuntut Umum, sedangkan terkait gugatan perdata saksi (korban) kepada saksi Gunawan Priambodo, Notaris hanya sebagai pihak turut tergugat dan hasil putusannya tidak memutuskan mengenai keabsahan atau akibat hukum akta Kuasa Menjual. Oleh karenanya, sangat diperlukan untuk melakukan penelitian hukum terkait akibat hukum terhadap obyek hukum Putusan Pidana tersebut yaitu akta Kuasa Menjual yang dibuat oleh Notaris tersebut melalui tesis ini yaitu dengan judul "Akibat Hukum Akta Kuasa

\footnotetext{
${ }^{15}$ Retno S. Darussalam, "Surat Kuasa Penjualan”, diakses dari https://www.hukumonline.com/klinik/detail/ulasan/lt4ca331071728a/surat-kuasa-penjualan/, pada tanggal 18 Maret 2020 Pukul 12.13.

${ }^{16}$ Habib Adjie, Hukum Notaris Indonesia Tafsir Tematik Terhadap UU Nomor 2 Tahun 2014 Tentang Perubahan Atas Undang-Undang Nomor 30 Tahun 2004 Tentang Jabatan Notaris, (Surabaya, PT. Refika Aditama, 2015), hlm. 1.
} 
Menjual Yang Dibuat Oleh Notaris Yang Memenuhi Unsur Sengaja Memberi Kesempatan Atau Sarana Dalam Tindak Pidana Penipuan (Studi Kasus Putusan Pengadilan Negeri Nomor 196/Pid.B/2019/PN Dps juncto Putusan Pengadilan Tinggi Nomor 27/Pid/2019/PT DPS)". Notaris sebagai pejabat umum harus menerapkan prinsip kehati-hatian dalam menjalankan kewajiban dan kewenangannya khususnya dalam pembuatan akta kuasa menjual dan memahami akibat hukum serta tanggung jawab Notaris terhadap akta Kuasa Menjual yang memenuhi unsur tindak pidana.

\section{PENDEKATAN TEORI}

1. Teori Hukum Pembuktian, khususnya pembuktian dalam hukum dalam acara pidana adalah ketentuan yang mengatur sidang pengadilan tentang ketentuan tata cara dan penilaian alat bukti sesuai dengan undang-undang, sehingga dalam menilai dan menggunakan alat bukti tidak boleh bertentangan dengan undangundang.

2. Teori Pertanggungjawaban Hukum, bahwa pertanggungjawaban Notaris diklasifikasikan menjadi aspek tanggunggugat keperdataan, aspek tanggung jawab administratif dan aspek tanggung jawab pidana.

\section{METODE PENELITIAN}

Jenis penelitian yang penulis gunakan dalam penelitian ini adalah penelitian yuridis normatif dengan menelaah permasalahan berdasarkan asas hukum dan hukum positif yang tertulis maupun tidak tertulis yang terkait dengan penelitian ini. ${ }^{17}$ Metode pendekatan yang digunakan dalam penelitian ini adalah pendekatan normatif yaitu dengan melakukan pendekatan masalah hukum yang akan diteliti dengan sifat hukum yang normatif. Dalam penelitian ini dilakukan pengamatan dan analisis terhadap putusan pengadilan dan menganalisis terhadap peraturan perundang-undangan yang berlaku. Teknik pengumpulan data ini menggunakan studi kepustakaan. Studi kepustakaan yaitu pengumpulan data-data yang diperoleh melalui bahan pustaka yang berisikan informasi tentang bahan primer. Studi kepustakaan diperoleh dengan mempelajari literatur-literatur yang berhubungan dengan obyek dan permasalahan yang diteliti. Jenis data yang peneliti gunakan yaitu jenis data sekunder, mencakup dokumen-dokumen resmi, buku-buku, hasil-hasil penelitian yang berwujud laporan, buku harian dan seterusnya. ${ }^{18}$ Penyajian data dideskripsikan dalam bentuk essay menggunakan kalimat-kalimat yang bersifat membahas dan menguraikan permasalahan yang diteliti. Metode analisis data yang peneliti gunakan yaitu dengan metode kualitatif, yaitu apa yang dinyatakan oleh sasaran penelitian yang bersangkutan secara tertulis. ${ }^{19}$ Bentuk hasil penelitian yang peneliti sajikan adalah bentuk deskriptif-analitis.

17 Sri Mamuji, Et al, Metode Penelitian dan Penulisan Hukum, (Jakarta: Badan Penerbit Hukum Universitas Indonesia, 2005), hlm. 10.

18 Soerjono Soekanto, Pengantar Penelitian Hukum, cet.3, (Jakarta: UI-Press, 1986), hlm. 12.

${ }^{19}$ Sri Mamuji, Et al, op.cit., hlm. 67. 
Otentik's: Jurnal Hukum Kenotariatan (Vol 2, No. 1, Januari 2020)

p-ISSN 2655-5131 e-ISSN 2685-3612

\section{HASIL PENELITIAN}

\section{KASUS POSISI DAN LATAR BELAKANG PERKARA}

Ketut Neli Asih, SH adalah berprofesi sebagai Notaris di Kabupaten Badung (untuk selanjutnya disebut dengan Terdakwa), telah mengenal saksi Gunawan Priambodo dan saksi (korban) Marhendro Anton Inggriyono (untuk selanjutnya disebut saksi (korban)), yang keduanya merupakan pebisnis/agen properti di Bali. Pada tanggal 8 Agustus 2014, Terdakwa didatangi oleh saksi Sugiartini yang merupakan staff saksi Gunawan Priambodo, dengan membawa surat kelengkapan tanah yang berlokasi di Perumahan Taman Griya Komplek Villa Paradise Loft (selanjutnya disebut dengan Tanah Paradise Loft) berupa Sertipikat Hak Guna Bangunan Nomor 7062/Kelurahan Benoa seluas $5.455 \mathrm{~m} 2$ atas nama PT. NUANSA BALI UTAMA (selanjutnya disebut dengan SHGB Nomor 7062) untuk dibuatkan perjanjian jual beli antara saksi Gunawan Priambodo dengan saksi (korban) .

Bahwa dikarenakan SHGB Nomor 7062 tersebut belum atas nama Gunawan Priambodo sebagai penjual melainkan masih atas nama PT. NUANSA BALI UTAMA sehingga tidak bisa dibuatkan akta jual beli, maka selanjutnya atas kesepakatan para pihak dibuatkanlah Akta Kuasa Menjual oleh Terdakwa. Menurut keterangan saksi Sugiartini bahwa saksi Gunawan Priambodo dan saksi (korban) menyetujui cara pembayaran tanah tersebut adalah dengan cara menghapus piutang milik saksi (korban) yang masih berada pada diri saksi Gunawan Priambodo, kemudian mengakumulasikan piutang tersebut bersama dengan beberapa transaksi antara saksi Gunawan Priambodo dengan saksi (korban) yang gagal kurang lebih sejumlah Rp.11.673.500.000,- (sebelas miliar enam ratus tujuh puluh tiga juta lima ratus ribu Rupiah).

Dengan kondisi SHGB Nomor 7062 masih atas nama PT. NUANSA BALI UTAMA tersebut, Terdakwa menyanggupi pembuatan Akta Kuasa Menjual, sehingga SHGB tersebut disimpan di kantor Terdakwa, namun pada tanggal 13 Agustus 2014 saksi Sugiartini mengaku diperintahkan oleh saksi Gunawan Priambodo untuk mengambil kembali SHGB Nomor 7062 dengan alasan akan melakukan pengurusan pemecahan dan kemudian Terdakwa memberikan SHGB tersebut kepada saksi Sugihartini. Pada tanggal 4 September 2014, saksi Gunawan Priambodo bersama dengan saksi (korban) dan saksi Shanty Rahardjo datang ke kantor Terdakwa untuk melakukan transaksi dan perikatan, dengan membawa surat-surat berupa:

1. Perjanjian Pengikatan Jual Beli (PPJB) Nomor 30 tanggal 20 November 2012, antara saksi Gunawan Priambodo dengan PT. NUANSA BALI UTAMA, dibuat di hadapan saksi Putu Trisna Rosilawati, SH, MKn, Notaris di Kabupaten Badung;

2. Akta Kuasa Menjual Nomor 31 tanggal 20 November 2012, yang isinya PT. NUANSA BALI UTAMA memberikan kuasa kepada saksi Gunawan Priambodo untuk menjual sebidang tanah dengan luas $4.179 \mathrm{~m} 2$ dengan SHGB Nomor 6237/Benoa dari luas global seluas $6.063 \mathrm{~m} 2$, dibuat oleh saksi Putu Trisna Rosilawati, SH, MKn, Notaris di Kabupaten Badung;

Pada tanggal 4 September 2014 tersebut dibuatlah Akta Kuasa Menjual Nomor 3, di hadapan Terdakwa yang mana dalam premis akta menyebutkan saksi Gunawan Priambodo selaku pemberi kuasa telah menjual sebagian tanah seluas kurang lebih 2.962 $\mathrm{m} 2$ dan telah dibayar lunas oleh penerima kuasa yakni saksi (korban) dengan kesepakatan untuk pengurusan balik nama dan pemecahan SHGB Nomor 7062 akan dilakukan oleh saksi Gunawan Priambodo dalam jangka waktu 3 bulan setelah Akta Kuasa Menjual ditandatangani. 
Setelah 6 bulan sejak dibuatnya Akta Kuasa Menjual, saksi (korban) Marhendro Anton Inggriyono belum juga menerima hasil pemecahan atas SHGB Nomor 7062 baik dari Terdakwa maupun dari saksi Gunawan Priambodo. Saksi (korban) menanyakan kepada Terdakwa, Terdakwa menjelaskan bahwa SHGB Nomor 7062 sudah diambil sejak lama oleh saksi Sugiartini, sehingga saksi (korban) merasa kebingungan dan sangat dirugikan. Saksi (korban) sudah berusaha menghubungi saksi Gunawan Priambodo, namun tidak berhasil, hanya dapat menanyakan hal tersebut kepada saksi Sugiartini yang menerangkan bahwa SHGB Nomor 7062 sudah berada di kantor saksi Triska Damayanti, Notaris di Kabupaten Badung.

Saksi (korban) melakukan pengecekan ke kantor saksi Triska Damayanti, dan hanya dapat menemui saksi I Made Juli Ardika yang merupakan karyawan saksi Triska Damayanti, kemudian dijelaskan bahwa sebagian tanah SHGB Nomor 7062 seluas 1.746 m2 telah dijual oleh saksi Gunawan Priambodo kepada saksi Sriyanto dengan harga Rp.3.500.000.000,- (tiga miliar lima ratus juta Rupiah), sehingga saksi (korban) mencoba menemui saksi Sriyanto dan mendapat keterangan yang sama. Oleh karenanya saksi (korban) melakukan berbagai upaya kepada saksi Gunawan Priambodo untuk menagih/memperoleh kembali seluruh uang miliknya, yaitu dengan cara mengajukan gugatan perdata ke pengadilan setempat dan juga melaporkan saksi Gunawan Priambodo kepada pihak yang berwajib.

Bahwa Terdakwa di persidangan telah didakwa oleh Penuntut Umum dengan dakwaan sebagai berikut:

1. Perbuatan Terdakwa sebagaimana diatur dan diancam pidana dalam Pasal 372 KUHP juncto Pasal 56 ayat (2) KUHP.

2. Perbuatan Terdakwa sebagaimana diatur dan diancam pidana dalam Pasal 378 KUHP juncto Pasal 56 ayat (2) KUHP.

3. Perbuatan Terdakwa sebagaimana diatur dan diancam pidana dalam Pasal 385 KUHP juncto Pasal 56 ayat (2) KUHP.

Bahwa pada tanggal 25 April 2019 diputuskan berdasarkan hasil pertimbangan hukum Hakim dalam Putusan Nomor 196/Pid.B/2019/PN Dps, dengan putusan sebagai berikut:

1. Menyatakan Terdakwa Ketut Neli Asih, $\mathrm{SH}$ tersebut di atas, telah terbukti secara sah dan meyakinkan bersalah melakukan tindak pidana "Sengaja Memberi Kesempatan atau Sarana dalam tindak pidana Penipuan" sebagaimana dalam dakwaan kedua Penuntut Umum;

2. Menjatuhkan pidana kepada Terdakwa oleh karena itu dengan pidana penjara selama : 1 (satu) tahun dan 4 (empat) bulan;

3. Menetapkan masa penangkapan dan penahanan yang telah dijalani Terdakwa dikurangkan seluruhnya dari pidana yang dijatuhkan;

4. Menetapkan Terdakwa tetap ditahan;

5. Menetapkan barang bukti berupa:

- 1 (satu) bendel salinan Akta Kuasa Menjual Nomor 03 tanggal 4 September 2014;

- Salinan PPJB Nomor 30 tanggal 20 November 2012;

- Salinan Akta kuasa Nomor 31 tanggal 20 November 2012;

- Salinan Akta pembatalan Nomor 5 tanggal 4 Juli 2014;

- Salinan Akta pencabutan kuasa Nomor 6 tanggal 4 Juli 2014;

- Dan barang bukti lain yang terlampir dalam Putusan Pengadilan Nomor 196/Pid.B/2019/PN Dps.

Dipergunakan dalam pembuktian perkara atas nama Terdakwa Gunawan Priambodo. 
6. Membebankan kepada Terdakwa untuk membayar biaya perkara sebesar Rp.2.000,- (dua ribu Rupiah).

Bahwa berdasarkan Akta Permintaan Banding yang dibuat oleh Panitera Pengadilan Negeri Denpasar menerangkan bahwa Terdakwa melalui Penasehat Hukumnya telah menyatakan banding pada tanggal 30 April 2019 dan permintaan banding tersebut telah diberitahukan pula kepada Penuntut Umum pada tanggal 13 Mei 2019. Pada tanggal 27 Juni 2019 diputuskan berdasarkan hasil pertimbangan hukum Hakim dalam Putusan Nomor 27/Pid/2019/PT DPS, dengan sebagai berikut:

1. Menerima permintaan banding dari Terdakwa Ketut Neli Asih, SH tersebut;

2. Memperbaiki putusan Pengadilan Negeri Denpasar Nomor 196/Pid.B/2019/PN Dps tanggal 25 April 2019 yang dimohonkan banding tersebut sekedar mengenai pidana yang dijatuhkan kepada Terdakwa sehingga amarnya berbunyi sebagai berikut:

"Menjatuhkan pidana kepada Terdakwa oleh karena itu dengan pidana penjara selama: 1 (satu) tahun dan 2 (dua) bulan";

3. Menguatkan putusan Pengadilan Negeri Denpasar Nomor 196/Pid.B/2019/PN Dps tanggal 25 April 2019 untuk selebihnya;

4. Menetapkan Terdakwa tetap berada dalam tahanan;

5. Membebankan biaya perkara kepada Terdakwa dalam kedua tingkat peradilan, yang di tingkat banding ditetapkan sejumlah Rp.5.000,- (lima ribu Rupiah).

\section{AKIBAT HUKUM AKTA KUASA MENJUAL YANG DIBUAT OLEH NOTARIS YANG MEMENUHI UNSUR MEMBERI KESEMPATAN ATAU SARANA DALAM TINDAK PIDANA PENIPUAN TERKAIT PUTUSAN PENGADILAN NEGERI NOMOR 196/Pid.B/2019/PN Dps juncto PUTUSAN PENGADILAN TINGGI NOMOR 27/Pid/2019/PT DPS}

Bahwa dalam Putusan Pengadilan Negeri Nomor 196/Pid.B/2019/PN Dps juncto Putusan Pengadilan Tinggi Nomor 27/Pid/2019/PT DPS, salah satu barang bukti yang menyebabkan Notaris menjadi Terdakwa dan diputus terbukti secara sah dan meyakinkan bersalah melakukan tindak pidana "sengaja memberi kesempatan atau sarana dalam tindak pidana penipuan" adalah produk akta kuasa menjual tanggal 4 September 2014 Nomor 03 (untuk selanjutnya disebut Akta Kuasa Menjual). Pembuatan Akta Kuasa Menjual tersebut adalah kesepakatan para pihak (dalam kasus ini adalah penjual dan pembeli), seharusnya perbuatan hukum yang dilakukan para pihak sebagaimana tercantum dalam kasus posisi adalah perbuatan hukum jual beli atas SHGB Nomor 7062 dengan cara pembayaran sebagian melalui akumulasi piutang saksi (korban) kepada saksi Gunawan Priambodo.

Bahwa terkait pembuktian terhadap kesalahan Terdakwa dalam hukum acara pidana menganut negatif wettelijk bewijstheorie, dasar pembuktian menurut keyakinan hakim timbul dari alat-alat bukti dalam undang-undang secara negatif. Alat bukti dalam hukum acara pidana tidak mengenal hierarki, hanya saja ada ketentuan-ketentuan yang mensyaratkan keterkaitan antar bukti yang satu dengan bukti yang lain. Oleh karena itu dalam hukum acara pidana terdapat bukti yang bersifat sebagai pelengkap, bukti tersebut timbul dari bukti yang lain. ${ }^{20}$

Pembuktian dalam hukum perdata didasarkan pada positif wettelijk bewijstheorie. Oleh karena itu, ada yang berpendapat bahwa kebenaran yang dicari dalam hukum perdata adalah kebenaran formal, artinya kebenaran yang hanya didasarkan pada alat

${ }^{20}$ Eddy O.S. Hieariej, Prinsip-Prinsip Hukum Pidana, (Yogyakarta: Cahaya Atma Pustaka, 2016), hlm. 25-26 
bukti semata sebagaimana disebutkan dalam undang-undang. ${ }^{21}$ Konsekuensi lebih lanjut, hakim dalam acara perdata memeriksa perkara hanya sebatas alat bukti yang diajukan para pihak. ${ }^{22}$ Alat bukti tertulis seperti surat atau sertipikat atau akta otentik mempunyai kekuatan yang sangat kuat, terlebih akta otentik adalah probatio plena yang berarti mempunyai kekuatan pembuktian penuh dan sempurna yang kedudukannya sangat kuat, kecuali dibuktikan sebaliknya. ${ }^{23}$

Menurut Pasal 1870 KUHPerdata atau Pasal 165 HIR, suatu akta otentik memberikan di antara para pihak beserta ahli warisnya atau orang-orang yang mendapat hak dari mereka suatu bukti yang sempurna, dalam arti bahwa ia tidak memerlukan suatu penambahan pembuktian tentang apa yang dimuat di dalamnya. ${ }^{24}$ Akta otentik itu merupakan suatu bukti yang mengikat, dalam arti bahwa apa yang ditulis dalam akta tersebut harus dipercaya oleh Hakim, harus dianggap sebagai yang benar, selama ketidakbenarannya tidak dibuktikan. ${ }^{25}$ Akta pemberian kuasa dalam bentuk akta notaris juga mempunyai pembuktian sempurna, apabila memenuhi nilai pembuktian akta otentik dari aspek lahiriah, formal dan materil.

Dalam hukum perdata "Lembaga Kuasa" tergolong perjanjian/persetujuan yang merupakan salah satu sumber adanya perikatan, selain undang-undang. Karena tergolong perikatan, lembaga kuasa tunduk dengan syarat sahnya perikatan yang diatur dalam Pasal 1320 KUHPerdata. ${ }^{26}$ Berdasarkan Pasal 1792 KUHPerdata perjanjian pemberian kuasa merupakan suatu perjanjian yang berisikan pemberian kekuasaan kepada orang lain yang menerimanya untuk melaksanakan sesuatu atas nama orang yang memberi kuasa. Salah satu bentuk pemberian kuasa adalah dengan akta umum yang merupakan suatu pemberian kuasa yang dilakukan antara pemberi kuasa dan penerima kuasa dengan menggunakan akta notaris atau akta notaril, artinya bahwa pemberian kuasa ini dilakukan di hadapan dan di muka notaris. ${ }^{27}$

Pemberian kuasa adalah suatu perjanjian, untuk memeriksa sah atau tidaknya perjanjian dapat dipastikan dengan mengujikannya terhadap empat syarat untuk sahnya suatu perjanjian sebagaimana diatur dalam Pasal 1320 KUHPerdata, yaitu:

1. Sepakat mereka yang mengikatkan dirinya;

2. Kecakapan untuk membuat suatu perikatan;

3. Suatu hal tertentu; dan

4. Suatu sebab yang halal. ${ }^{28}$

${ }^{21}$ Ibid., hlm. 16

${ }^{22}$ Ibid.

${ }^{23}$ Ibid., hlm. 26.

${ }^{24}$ Koesparmono Irsan dan Armansyah, Panduan Memahami Hukum Pembuktian Dalam Hukum Perdata dan Hukum Pidana, (Jakarta: Gramata Publishing, 2016), hlm. 40.

${ }^{25}$ Ibid., hlm. 40

${ }^{26}$ I Ketut Oka Setiawan, “Lembaga Kuasa dan Kuasa Mutlak”, Jurnal Judical Volume III Nomor 2, 2008.

${ }^{27}$ Salim, Hukum Kontrak Teori \& Teknik Penyusunan Kontrak, (Jakarta: Sinar Grafika, 2015), hlm. 84-85.

${ }^{28}$ Herlin Budiono, Ajaran Umum Hukum Perjanjian dan Penerapannya di Bidang Kenotariatan, (Bandung: PT. Citra Aditya Bakti, 2019), hlm. 73. 
Dalam premis Akta Kuasa Menjual menerangkan adanya perbuatan hukum jual beli antara Pemberi Kuasa dan Penerima Kuasa dan kesepakatan mengenai proses pengurusan pemecahan atas SHGB Nomor 7062, yang berbunyi:

"PEMBERI KUASA menerangkan bahwa:

1. PEMBERI KUASA telah menjual sebagian tanah yang akan diuraikan di bawah ini kepada PENERIMA KUASA yaitu seluas \pm 2.962 M2 (kurang lebih dua ribu sembilan ratus enam puluh dua meter persegi) dan telah dibayar lunas oleh PENERIMA KUASA.

2. Sertipikat atas tanah tersebut sedang dilakukan pemecahan sertipikat oleh PEMBERI KUASA dan akan diselesaikan dalam jangka waktu 3 (tiga) bulan sejak akta ini ditanda-tangani yaitu pada tanggal empat Desember tahun dua ribu empat belas (04-12-2014).

3. Sehubungan dengan hal-hal tersebut, maka dengan ini memberi kuasa dengan hak subsitusi kepada:"

Bahwa konsep kuasa adalah wewenang yang diberikan oleh seseorang kepada orang lain, yang terikat adalah orang yang diwakilinya itu, asal saja orang yang bertindak dan yang diwakilinya terdapat suatu hubungan hukum. ${ }^{29}$ Dalam prinsipnya kuasa untuk menjual diberikan oleh pihak penjual (pemilik tanah) tidak dapat hadir sendiri pada saat penandatanganan akta jual beli karena alasan-alasan tertentu, misalnya pelaksanaan penjualan terjadi diluar kota atau ia tidak dapat meninggalkan pekerjaannya. ${ }^{30}$

Menurut keterangan saksi ahli kenotariatan yaitu I Made Pria Dharsana, sebagaimana ternyata dalam Putusan Pengadilan menerangkan bahwa dalam kenotariatan dikenal dua kuasa yakni kuasa mutlak dan kuasa mandiri, antara kedua kuasa ini berbeda, dalam kuasa mandiri bisa dicabut, misalnya orangnya meninggal dunia sehingga kuasa ini tidak bisa digunakan, sedangkan kuasa mutlak adalah kuasa dalam hal baik nama, apabila mereka yang membuat kuasa meninggal dunia masih bisa berlaku kepada ahli warisnya. Bahwa kuasa mutlak yang dimaksudkan disini adalah kuasa yang tidak bisa dicabut, yang dilarang adalah kuasa mandiri tidak didasarkan dalam perjanjian pokok, perjanjian yang mendahului kuasa pokok, kuasa menjual melekat tidak dipisahkan dengan perjanjian pelaksanaan.

Bahwa bukti pengikatan pemilikan pemberi kuasa saksi Gunawan Priambodo atas SHGB Nomor 7062 yang masih terdaftar atas nama PT. NUANSA BALI UTAMA dalam Akta Kuasa Menjual adalah Akta Pengikatan Jual Beli Nomor 30 dan Akta Kuasa Nomor 31, masing-masing tertanggal dua puluh November tahun dua ribu dua belas (20-112012) yang dibuat dihadapan saksi Putu Trisna Rosilawati, SH. Pada persidangan terungkap bahwa Akta Pengikatan Jual Beli dan Akta Kuasa tersebut ternyata sudah dibatalkan antara saksi Gunawan Priambodo dan PT. NUANSA BALI UTAMA, sebagaimana ternyata dalam Akta Pembatalan Nomor 5 dan Akta Pencabutan Kuasa Nomor 6, masing-masing tertanggal empat Juli tahun dua ribu empat belas (04-07-2014) yang dibuat dihadapan saksi Putu Trisna Rosilawati, SH. Berdasarkan fakta tersebut seharusnya yang berwenang untuk melakukan perbuatan hukum pemberian kuasa adalah PT. NUANSA BALI UTAMA sebagai pemegang hak atas tanah bukan saksi Gunawan Priambodo.

Bahwa pada bagian isi Akta Kuasa Menjual juga terdapat klausul, yaitu:

${ }^{29}$ I Ketut Oka Setiawan, loc.cit.

${ }^{30}$ Gedion Ardana Reswari, "Surat Kuasa Mutlak Pada Perjanjian Pengikatan Jual Beli Hak Atas Tanah”, Jurnal Rechtens, Vol.3, No. 1, 2014. 
"Kuasa ini diberikan dengan mengesampingkan ketentuan-ketentuan dan sebabsebab yang tercantum dalam Pasal 1813 Kitab Undang-Undang Hukum Perdata."

Pasal 1813 KUHPerdata adalah mengenai berakhirnya pemberian kuasa yaitu dengan ditariknya kembali kuasanya si kuasa, dengan pemberitahuan penghentian oleh si kuasa, dengan meninggalnya, pengampuannya atau pailitnya si pemberi kuasa maupun di penerima kuasa, dengan perkawinan si perempuan yang memberikan atau menerima kuasa (khusus ketentuan ini sudah tidak berlaku).

Dengan adanya klausul pengecualian tersebut berarti Akta Kuasa Menjual tidak dapat ditarik kembali oleh pemberi kuasa dan bahwa klausul tersebut bertentangan dengan/menyimpang dengan ketentuan undang-undang yang ada terutama Pasal 1813 KUHPerdata tersebut. Sedangkan pada Pasal 1814 KUHPerdata dijelaskan tentang adanya hak dari pemberi kuasa dapat menarik kembali kuasanya manakala dikehendaki, dengan demikian klausul kuasa yang tidak dapat dicabut kembali merupakan penyimpangan dari undang-undang.

Dalam Instruksi Menteri Dalam Negeri Nomor 14 Tahun 1982 Tentang Larangan Penggunaan Kuasa Mutlak Sebagai Pemindahan Hak Atas Tanah (untuk selanjutnya disebut Instruksi Mendagri Nomor 14 Tahun 1982) menjelaskan mengenai kuasa mutlak dalam diktum kedua, yaitu kuasa yang didalamnya mengandung unsur tidak dapat ditarik kembali oleh pemberi kuasa dan kuasa yang memberikan kewenangan kepada penerima kuasa untuk menguasai dan menggunakan tanahnya serta melakukan segala perbuatan hukum yang menurut hukum dapat dilakukan oleh pemegang hak. ${ }^{31}$ Bahwa perbuatan hukum yang dimaksud dalam Instruksi Mendagri Nomor 14 Tahun 1982 adalah perbuatan memindahkan/mengalihkan hak atas tanah secara terselubung, yakni suatu transaksi yang dalam hakekatnya merupakan suatu pemindahan/pengalihan hak atas tanah, akan tetapi dilakukan dengan cara yang tidak sesuai dengan prosedur yang diatur dalam Pasal 19 Peraturan Pemerintah Nomor 10 Tahun 1962 juncto Peraturan Pemerintah Nomor 24 Tahun 1997 Pasal 39 huruf D yaitu dengan membuat akta jual beli di hadapan Pejabat Pembuat Akta Tanah (PPAT), tetapi dilakukan dengan memberikan kuasa mutlak kepada pembeli, yang berdasarkan kuasa tersebut dapat melakukan segala tindakan dan perbuatan hukum mengenai tanah yang bersangkutan, semuanya sebagaimana yang dapat dilakukan oleh si pemberi kuasa sendiri selaku pemilik. ${ }^{32}$

Larangan penggunaan kuasa mutlak juga diatur dalam Pasal 39 ayat (1) huruf d Peraturan Pemerintah Nomor 24 Tahun 1997 tentang Pendaftaran Tanah yang menyebutkan bahwa "PPAT menolak untuk membuat akta jika salah satu pihak atau para pihak bertindak atas dasar suatu surat kuasa mutlak yang pada hakikatnya berisikan perbuatan hukum pemindahan hak". Bahwa berdasarkan Peraturan Kepala Badan Pertanahan Republik Indonesia Nomor 10 Tahun 2014 tentang Pencabutan Peraturan Perundang-undangan Mengenai Pertanahan pada lampiran angka 80 telah mencabut Instruksi Mendagri Nomor 14 Tahun 1982 tersebut. Meskipun demikian Instruksi Mendagri Nomor 14 Tahun 1982 masih menjadi acuan, dikarenakan larangan penggunaan kuasa mutlak diatur juga dalam Pasal 39 ayat (1) huruf d Peraturan Pemerintah Nomor 24 Tahun 1997 yang saat ini masih berlaku adalah sama dengan larangan penggunaan kuasa mutlak yang diatur dalam Instruksi Mendagri Nomor 14

\footnotetext{
${ }^{31}$ Clara Vania dan Gunawan Djajaputra, loc.cit.

${ }^{32}$ Gedion Ardana Reswari, loc.cit.
} 
Tahun 1982 tersebut. ${ }^{33}$ Oleh karenanya berdasarkan ketentuan tersebut Akta Kuasa Menjual yang memenuhi unsur kuasa mutlak dan memuat unsur jual beli tidak dapat bisa digunakan sebagai dasar pengurusan akta jual beli yang dibuat di hadapan PPAT dan tentunya merugikan pihak pembeli atau penerima kuasa.

Beberapa yurisprudensi yang menyatakan larangan terhadap pengunaaan surat kuasa mutlak yaitu antara lain:

1. Mahkamah Agung Nomor 3332 K/Pdt/1994, tanggal 18 Desember 1997. ${ }^{34}$

Kaidah Hukum: Akta kuasa mutlak yang dibuat oleh seorang Notaris sebagai sarana untuk melaksanakan jual beli tanah, tidak dapat diajukan sebagai bukti di persidangan pengadilan, tentang adanya peralihan hak atas tanah dari penjual kepada pembeli. Hal ini disebabkan karena "Kuasa Mutlak" adalah bertentangan dan dilarang oleh Instruksi Mendagri Nomor 14 Tahun 1982 yang telah diperkuat oleh Yurisprudensi Mahkamah Agung, dengan dasar alasan bahwa "Kuasa Mutlak" mengandung perkosaan hak penjual yang lemah ekonominya dan tidak adanya kebebasan berkontrak.

2. Mahkamah Agung Nomor 1440 K/Pdt/1996, tanggal 30 Juni $1998 .{ }^{35}$

Kaidah Hukum: "Kuasa Mutlak" yang tercantum dalam Akta Nomor 07/tanggal 12 Mei 1992, adalah bertentangan dengan Instruksi Mendagri Nomor 14 Tahun 1982, sehingga batal demi hukum.

3. Mahkamah Agung Nomor $316 \mathrm{PK} / \mathrm{Pdt} / 2000$, tanggal 29 Juni $2004 .^{36}$

Kaidah Hukum: Akta Perjanjian Pengikatan Jual Beli Tanah yang dibuat oleh Notaris yang didasarkan pada "Akta Kuasa Mutlak" adalah dilarang baik oleh Instruksi Mendagri Nomor 14 Tahun 1982 serta adanya "Yurisprudensi tetap" Mahkamah Agung. Akta Notaris yang berisi demikian itu adalah tidak sah menurut hukum.

4. Mahkamah Agung Nomor 119 K/TUN/2000, tanggal 17 Oktober 2002 juncto Nomor 3176 K/Pdt $/ 1988 .^{37}$

Kaidah Hukum: Akta pemindahan kuasa yang berisi "penerima kuasa memiliki kuasa atas tanah-tanah yang disebutkan dalam kuasa tersebut" adalah sama dengan akta kuasa mutlak tentang perolehan hak atas tanah dari "Pemilik Tanah" kepada pihak lain, yang menurut Instruksi Mendagri Nomor 14 Tahun 1982 juncto Nomor 12/Tahun 1984, hal tersebut adalah dilarang, karena dinilai sebagai suatu penyelundupan hukum dalam "perolehan hak atas tanah". Di samping itu, juga merupakan pelanggaran/penyimpangan Pasal 1813 KUHPerdata.

5. Mahkamah Agung Nomor 1400 K/Pdt/2001, tanggal 2 Januari 2003

Kaidah Hukum:

- Barang jaminan hanya dapat dijual melalui lelang. Bank tidak berhak menjual sendiri tanah yang dijaminkan pada Bank tanpa seijin pemilik.

${ }^{33}$ Clara Vania dan Gunawan Djajaputra, loc.cit,

${ }^{34}$ Hulman Panjaitan, Kumpulan Kaidah Hukum Putusan Mahkamah Agung Republik Indonesia Tahun 1953 s/d 2008 Berdasarkan Penggolongannya, (Jakarta: Kencana, 2014), hlm. 18 .

\footnotetext{
${ }^{35}$ Ibid., hlm. 19.

${ }^{36}$ Ibid., hlm. 19-20.

${ }^{37}$ Ibid., hlm. 20.
} 
- Pengalihan hak atas tanah berdasarkan surat kuasa mutlak adalah batal demi hukum.

- Bantahan terhadap pelaksanaan putusan, maka yang berwenang untuk memeriksa dan memutus bantahan adalah Pengadilan dalam wilayah hukumnya yang menjalankan putusan.

Berdasarkan Surat Direktur Jenderal Agraria Nomor 594/493/AGR tidak semua penggunaan kuasa mutlak mengenai jual beli tanah dilarang, selama penggunaan kuasa tersebut bukan dimaksudkan untuk memindahkan hak atas tanah. Dari ketentuan tersebut penggunaan kuasa mutlak dalam perjanjian pengikatan jual beli tanah bukan termasuk dengan penggunaan kuasa mutlak yang dilarang, dengan catatan bahwa penggunaan kuasa mutlak tersebut harus merupakan satu kesatuan yang tidak dapat dipisahkan dari perjanjian pokoknya yaitu perjanjian pengikatan jual beli tanah (lunas).

Dari uraian tersebut di atas, bahwa pemberian kuasa dalam Akta Kuasa Menjual merupakan kuasa yang berdiri sendiri yang sebelumnya tidak dibuat atau didasarkan pada perjanjian pokok atau perjanjian pengikatan beli (lunas) dan memuat kuasa mutlak yang didalamnya mengandung unsur yang tidak dapat ditarik kembali oleh pemberi kuasa dan pada hakekatnya merupakan pemindahan hak atas tanah bertentangan dengan peraturan berlaku yaitu KUHPerdata dan Peraturan Pemerintah Nomor 24 Tahun 1997. Berdasarkan ketentuan Pasal 1337 KUHPerdata menyatakan bahwa suatu sebab adalah terlarang apabila dilarang oleh undang-undang atau apabila berlawanan dengan kesusilaan baik atau ketertiban umum. Artinya suatu perjanjian dilakukan dengan kausa yang dilarang jika kausanya bertentangan, baik dengan norma-norma dari hukum yang tertulis maupun yang tidak tertulis. ${ }^{38}$ Dan ketentuan Pasal 1335 KUHPerdata menyatakan bahwa:

"Suatu perjanjian tanpa sebab atau yang telah dibuat karena sesuatu sebab yang palsu atau terlarang, tidak mempunyai kekuatan (hukum). Dengan kata lain, batal demi hukum."

Oleh karenanya berdasarkan uraian tersebut di atas Akta Kuasa Menjual tersebut tidak memenuhi syarat sah perjanjian yaitu sebab yang halal sehingga beresiko batal demi hukum.

Bahwa cacatnya akta notaris dapat menimbulkan kebatalan bagi suatu akta notaris, ditinjau dari sanksi atau akibat hukum dari kebatalan dibedakan menjadi:

1. Batal demi hukum van rechtwege njetig;

2. Dapat dibatalkan vernietigbaar;

3. Non existent. ${ }^{39}$

Akibat hukum dari suatu kebatalan pada prinsipnya sama antara batal demi hukum, dapat dibatalkan atau non existent, yaitu ketiganya mengakibatkan perbuatan hukum tersebut menjadi tidak berlaku atau perbuatan hukum tersebut tidak mempunyai akibat hukum. ${ }^{40}$ Titik perbedaannya pada waktu berlakunya kebatalan tersebut, yaitu: ${ }^{41}$

${ }^{38}$ Herlin Budiono, ibid, hlm.112.

${ }^{39}$ Sjaifurrachman dan Habib Adjie, Op.Cit. hlm.125

${ }^{40}$ Ibid.

41 Herlien Budiono, Kumpulan Tulisan Hukum Perdata di Bidang Kenotariatan, (Bandung: Citra Aditya Bandung, 2007), hlm. 363-389. 
1. Batal demi hukum, akibatnya perbuatan hukum yang dilakukan tidak mempunyai akibat hukum sejak terjadinya perbuatan hukum tersebut atau berdaya surut (ex tunc), dalam praktek batal demi hukum didasarkan pada putusan pengadilan yang telah mempunyai kekuatan hukum tetap.

2. Dapat dibatalkan, akibatnya perbuatan hukum yang dilakukan tidak mempunyai akibat hukum sejak terjadinya pembatalan, dan dimana pembatalan atau pengesahan perbuatan hukum tersebut tergantung pada pihak tertentu yang menyebabkan perbuatan hukum tersebut dapat dibatalkan. Akta yang sanksinya dapat dibatalkan, tetap berlaku dan mengikat selama belum ada putusan pengadilan yang telah mempunyai kekuatan hukum tetap yang membatalkan akta tersebut.

3. Non existent, akibatnya perbuatan hukum yang dilakukan tidak ada atau non existent yang disebabkan tidak dipenuhinya essensialia dari suatu perjanjian atau tidak memenuhi salah satu unsur, atau semua unsur dalam suatu perbuatan hukum tertentu. Sanksi non existent secara dogmatis tidak diperlukan putusan pengadilan namun dalam praktek tetap diperlukan putusan pengadilan yang mempunyai kekuatan hukum tetap dan implikasinya sama dengan batal demi hukum.memenuhi syarat sah perjanjian yaitu sebab yang halal sehingga beresiko batal demi hukum.

Bahwa Notaris telah didakwa oleh Penuntut Umum dengan dakwaan alternatif sebagaimana dijelaskan dalam kasus posisi poin A di atas. Majelis Hakim berdasarkan Putusan Pengadilan memilih dakwaan alternatif kedua melanggar Pasal 378 juncto Pasal 56 ayat 2 KUHP yang berdasarkan fakta-fakta hukum yang terungkap dalam persidangan yang dianggap paling tepat, yang salah satu unsurnya adalah memberi kesempatan, sarana atau keterangan, pertimbangan hakim dalam Putusan Pengadilan tersebut adalah:

1. Bahwa dari fakta hukum yang telah terungkap bahwa benar Terdakwa menyadari mengenai adanya alas hak yang tidak jelas karena hanya berupa fotokopi SHGB Nomor 7062, dan sudah dilakukannya pembatalan PPJB dan pencabutan akta kuasa menjual yang menjadi dasar pembuatan Akta Kuasa Menjual serta tidak didahului oleh suatu perjanjian perikatan. Terdakwa tidak melakukan upaya apapun untuk menghentikan pembuatan akta tersebut atau paling tidak berusaha menjamin proses pemecahan dan balik nama SHGB Nomor 7062. Sebagai seorang Notaris, tentunya mengetahui bahwa dalam pembuatan Akta Kuasa Menjual harus berdasarkan pada perikatan jual beli, karena antara perikatan jual beli dan akta kuasa menjual adalah satu kesatuan. Terdakwa dalam hal ini tetap memberi kesempatan kepada saksi Gunawan Priambodo untuk melakukan tindak pidana (penipuan) dengan memberikan sarana berupa Akta Kuasa Menjual tersebut.

2. Dengan demikian saksi Gunawan Priambodo menguasai seluruh uang dan piutang milik saksi (korban) tanpa harus khawatir apabila tidak mampu memenuhi isi kesepakatan tersebut karena SHGB Nomor 7062 masih berada dalam penguasaan saksi Gunawan Priambodo di kantor saksi Triska Damayanti. Oleh karena tindak pidana merupakan suatu delik materiil, yang mengharuskan adanya akibat yang timbul dari perbuatan pelaku maka tindakan Terdakwa yang memberikan kesempatan atau sarana kepada saksi Gunawan Priambodo untuk melakukan tindak pidana merupakan sebuah syarat mutlak agar perbuatan saksi Gunawan Priambodo menjadi suatu delik yang utuh.

Dalam menjalankan kewenangan tersebut notaris harus memperhatikan ketentuan Pasal 16 UUJN mengenai kewajiban notaris, salah satunya adalah bertindak jujur, seksama, mandiri, tidak berpihak dan menjaga kepentingan pihak lain yang terkait 
dalam perbuatan hukum. Notaris wajib memenuhi semua ketentuan jabatan notaris dan peraturan-peraturan lainnya, bukan juru tulis semata-mata namun Notaris perlu mengkaji apakah yang diinginkan penghadap untuk dinyatakan dalam akta otentik, tidak bertentangan dengan UUJN dan aturan yang berlaku. Kewajiban untuk mengetahui dan memahami syarat-syarat otentisitas, keabsahan dan sebab-sebab kebatalan suatu akta Notaris, sangat penting untuk menghindari secara preventif adanya cacat hukum akta Notaris yang mengakibatkan hilangnya otentisitas dan batalnya akta Notaris, yang dapat merugikan kepentingan masyarakat, terutama pihak-pihak yang berkepentingan. ${ }^{42}$

Berkaitan dengan kasus di atas, Notaris dalam melaksanakan kewenangannya membuat akta terikat kewajiban untuk menerapkan prinsip kehati-hatian (bertindak secara seksama) dan konsep hubungan notaris kepada para pihak/penghadap sebagaimana tersebut di atas. Prinsip kehati-hatian adalah suatu asas yang menyatakan bahwa Notaris dalam menjalankan tugas dan jabatannya harus lebih berhati-hati. Pelaksanaan asas ini wajib dilakukan dalam pembuatan akta, yaitu dengan:

1. Melakukan pengenalan terhadap penghadap, berdasarkan identitasnya yang diperlihatkan kepada Notaris.

2. Menanyakan kemudian mendengarkan dan mencermati keinginan atau kehendak para pihak tersebut.

3. Memeriksa bukti surat yang berkaitan dengan keinginan atau kehendak para pihak tersebut.

4. Memberikan saran dan membuat kerangka akta untuk memenuhi keinginan atau kehendak para pihak tersebut.

5. Memenuhi segala teknik administratif pembuatan akta Notaris, seperti pembacaan, penandatanganan, memberikan salinan dan pemberkasan untuk minuta.

6. Melakukan kewajiban lain yang berkaitan dengan pelaksanaan tugas jabatan Notaris. $^{43}$

Kebenaran akta Notaris adalah kebenaran formal, bahwa dasar pembuatan akta mengacu pada identitas komparan dan dokumen-dokumen formal sebagai pendukung untuk suatu perbuatan hukum, sehingga akta yang dibuat Notaris adalah bersifat kebenaran formal, disebut begitu karena Notaris tidak melakukan penelusuran dan penelitian sampai ke lapangan tentang dokumen formal yang dilampirkan sehingga akta Notaris bukan kebenaran materiil sebagaimana pencarian kebenaran dan keadilan dalam proses hukum di pengadilan. ${ }^{44}$ Meskipun demikian, sehubungan dengan pembuatan Akta Kuasa Menjual pada kasus tersebut, seharusnya Terdakwa wajib mengecek dokumendokumen yang menjadi dasar pembuatan Akta Kuasa Menjual dalam rangka menerapkan prinsip kehati-hatian.

Bahwa berdasarkan uraian tersebut, Akta Kuasa Menjual yang memenuhi unsur memberi kesempatan atau sarana dalam tindak pidana penipuan pada premis akta memuat klausul jual beli dan merupakan kuasa mutlak yaitu kuasa yang didalamnya mengandung unsur tidak dapat ditarik kembali oleh pemberi kuasa dan pada hakekatnya merupakan

\footnotetext{
${ }^{42}$ Sjaifurrachman dan Habib Adjie, Op.Cit. hlm.121

${ }^{43}$ Habib Adjie, Meneropong Khasanah Notaris dan PPAT Indonesia (Kumpulan Notaris dan PPAT), (Bandung: P.T Citra Aditya Bakti, 2009 ), hlm. 86.

44 Ahmad Reza Andhika, "Pertanggungjawaban Notaris Dalam Perkara Pidana Berkaitan Dengan Akta Yang Dibuatnya Menurut Undang-Undang Nomor 30 Tahun 2004", Premis Law Jurnal, 2016.
} 
pemindahan hak atas tanah serta memberikan kewenangan kepada penerima kuasa untuk menguasai dan menggunakan tanahnya serta melakukan segala perbuatan hukum yang menurut hukum dapat dilakukan oleh pemegang hak. Berdasarkan Pasal 39 ayat (1) huruf (d) Peraturan Pemerintah Nomor 24 Tahun 1997 tentang Pendaftaran Tanah menyebutkan bahwa PPAT menolak untuk membuat akta jika salah satu pihak atau para pihak bertindak atas dasar suatu surat kuasa mutlak yang pada hakikatnya berisikan perbuatan hukum pemindahan hak. Oleh karenanya Akta Kuasa Menjual tersebut tidak dapat digunakan sebagai dasar pengurusan akta jual beli yang dibuat di hadapan PPAT dan tentunya merugikan pihak pembeli atau penerima kuasa serta beresiko batal demi hukum. Bahwa dalam pembuatan Akta Kuasa Menjual, wajib terikat kewajiban untuk menerapkan prinsip kehati-hatian sebagaimana tercantum dalam Pasal 16 ayat (1) huruf (a) UUJN.

\section{PERTANGGUNGJAWABAN NOTARIS TERHADAP AKTA KUASA MENJUAL YANG MEMENUHI UNSUR MEMBERI KESEMPATAN ATAU SARANA DALAM TINDAK PIDANA PENIPUAN TERKAIT PUTUSAN PENGADILAN NEGERI NOMOR 196/Pid.B/2019/PN Dps juncto PUTUSAN PENGADILAN TINGGI NOMOR 27/Pid/2019/PT DPS}

Bahwa kehadiran jabatan Notaris dikehendaki oleh aturan hukum dengan maksud untuk membantu dan melayani masyarakat yang membutuhkan alat bukti tertulis yang bersifat otentik mengenai keadaan, peristiwa atau perbuatan hukum. Notaris dalam menjalankan jabatannya tersebut terikat pada kewajiban dan larangan tertentu yang ditentukan dalam UUJN sehingga dalam pelaksanaan jabatannya diperlukan kecermatan, ketelitian dan ketetapan tidak hanya dalam teknis administratif membuat akta, tetapi juga dalam penerapan berbagai aturan hukum yang tertuang dalam akta yang bersangkutan untuk para penghadap.

Dalam hal Notaris tidak melakukan ketentuan dalam UUJN dan peraturan perundang-undangan lainnya yang berkaitan dalam pelaksanaan tugasnya, Notaris dapat diberikan sanksi-sanksi terhadap pelanggaran tersebut. Sanksi yang ditujukan terhadap Notaris merupakan penyadaran, bahwa Notaris dalam melakukan tugas jabatannya telah melanggar ketentuan-ketentuan mengenai pelaksanaan tugas jabatan Notaris sebagaimana tercantum dalam UUJN dan untuk mengembalikan tindakan Notaris dalam melaksanakan tugas jabatannya untuk tertib sesuai dengan UUJN. ${ }^{45}$ Pemberian sanksi tersebut juga untuk melindungi masyarakat dari tindakan Notaris yang dapat merugikan dan menjaga martabat Lembaga Notaris sebagai lembaga kepercayaan, karena apabila Notaris melakukan pelanggaran, dapat menurunkan kepercayaan masyarakat terhadap Notaris. Sanksi tersebut dapat berupa sanksi perdata, administrasi dan kode etik jabatan notaris sebagaimana telah diatur dalam dalam UUJN dan Kode Etik bahkan sanksi pidana.

Bahwa tanggung jawab notaris dalam menjalankan tugas jabatannya berdasarkan kode etik notaris merupakan konsekuensi notaris sebagai suatu profesi. Kode etik menghendaki agar notaris mendapat acuan dalam menjalankan tugas jabatannya sebagai pejabat umum selain harus tunduk pada UUJN, juga harus tunduk pada kode etik profesi serta harus bertanggung jawab terhadap masyarakat yang dilayaninya. Dengan adanya hubungan tersebut, maka terhadap notaris yang mengabaikan keluhuran dari martabat

\footnotetext{
${ }^{45}$ Sjaifurrachman dan Habib Adjie, Op.Cit. hlm. 194.
} 
jabatannya, selain dapat dikenakan sanksi moril, ditegur atau dipecat dari keanggotaan profesinya, juga dapat dipecat dari jabatannya sebagai notaris. ${ }^{46}$

Bahwa sanksi keperdataan adalah sanksi yang dijatuhkan terhadap kesalahan yang terjadi karena wanprestasi atau perbuatan melanggar hukum onrechtmatige daad. ${ }^{47}$ Dalam pengajuan gugatan ganti rugi atas wanprestasi disyaratkan adanya kerugian yang timbul dan adanya hubungan causal atau sebab akibat antara timbulnya kerugian dan perbuatan melanggar norma yang dilakukan para pihak. Sedangkan dalam hal gugatan karena perbuatan melanggar hukum diberlakukan Pasal 1365 KUHPerdata. Langkah preventif menyikapi perbuatan Notaris, maka yang dikenakan adalan sanksi mengenai ganti rugi Pada onrechtmatige daad bentuk ganti rugi berbeda dengan ganti rugi atas dasar wanprestasi. Pada ganti rugi karena onrechtmatige daad, terbuka kemungkinan ganti rugi dalam bentuk lain selain jumlah uang. Syarat ganti rugi dalam bentuk lain yang bukan uang adalah ditentukan oleh penggugat dan hakim menganggapnya cocok. ${ }^{48}$

Terkait aspek tanggung gugat secara perdata, suatu akta yang dinyatakan batal demi hukum, maka akta tersebut dianggap tidak pernah ada atau tidak pernah dibuat, sesuatu yang tidak pernah dibuat tidak dapat dijadikan dasar suatu tuntutan dalam bentuk penggantian biaya, ganti rugi dan bunga. Dengan demikian seharusnya suatu akta Notaris yang batal demi hukum tidak menimbulkan akibat hukum untuk memberikan penggantian biaya, ganti rugi atau bunga kepada pihak yang tersebut dalam akta. ${ }^{49}$ Apabila ada pihak yang merasa dirugikan sebagai akibat langsung dari suatu akta Notaris, maka yang bersangkutan dapat menuntut secara perdata kepada Notaris. Tuntutan penggantian biaya, ganti rugi dan bunga terhadap Notaris tidak didasarkan atas penilaian atau kedudukan suatu alat bukti yang berubah karena melanggar ketentuan-ketentuan menurut Pasal 84 UUJN, tetapi hanya dapat didasarkan pada hubungan hukum yang ada atau yang terjadi antara Notaris dengan para penghadap. ${ }^{50}$ Berdasarkan keterangan saksi (korban) dalam persidangan yang ternyata dalam Putusan Pengadilan menyatakan:

"Bahwa terkait dengan dibuatnya Akta Kuasa Menjual oleh Notaris, saksi merasa tidak dirugikan, malah terbalik saksi merasa diuntungkan, saksi merasa sebagai pemilik sikap dan pendirian saksi itu dibuat atas dasar kesepakatan Bersama dengan Gunawan Priambodo.”

Pertanggungjawaban pidana adalah konsep pertanggungjawaban terhadap pelaku tindak pidana sebagai subyek hukum pidana dalam mempertanggungjawabkan perbuatannya yang memenuhi syarat-syarat pertanggungjawaban perbuatannya yang memenuhi syarat-syarat pertanggungjawaban pidana (asas kesalahan) karena melanggar pasal-pasal tertentu dari aturan pidana yang mengancam sanksi pidana bagi yang

46 Heriyanti, Pertanggungjawaban Pidana Notaris Dalam Kedudukannya Sebagai Pejabat Umum Terhadap Akta Otentik Yang Terindikasi Tindak Pidana, (Yuma Pustaka), hlm. 93.

${ }^{47}$ Sjaifurrachman dan Habib Adjie, op.cit., hlm. 195

${ }^{48}$ Ibid., hlm. 197.

${ }^{49}$ Ibid., hlm. 196.

${ }^{50}$ Ibid. 
melanggarnya. ${ }^{51}$ Bahwa terkait aspek tanggung jawab pidana, UUJN tidak mengatur tentang sanksi pidana terhadap Notaris, namun dalam praktek ditemukan kenyataan bahwa suatu tindakan hukum atau pelanggaran yang dilakukan Notaris terkait akta otentik yang dibuatnya dikualifikasikan sebagai suatu tindak pidana. ${ }^{52}$ Oleh karenanya jika seorang Notaris diduga melakukan pelanggaran pidana terkait akta yang dibuatnya, maka Notaris tersebut dapat dikenakan sanksi pidana yang mengacu pada ketentuan-ketentuan hukum yang terdapat dalam KUHP. Bahwa dengan catatan pemidanaan terhadap Notaris dilakukan dengan batasan, yaitu:

1. Ada tindakan hukum dari Notaris terhadap aspek lahiriah, formal dan materil akta yang sengaja, penuh kesadaran dan keinsyafan, serta direncanakan bahwa akta yang akan dibuat di hadapan Notaris atau oleh Notaris bersama-sama (sepakat) para penghadap dijadikan dasar untuk melakukan suatu tindak pidana;

2. Ada tindakan hukum dari Notaris dalam membuat akta di hadapan atau oleh Notaris yang apabila diukur berdasarkan UUJN tidak sesuai dengan UUJN;

3. Tindakan Notaris tersebut juga tidak sesuai menurut instansi yang berwenang untuk menilai tindakan suatu Notaris, dalam hal ini Majelis Pengawas Notaris.

Bahwa Notaris berdasarkan Putusan Pengadilan telah didakwa oleh Penuntut Umum dengan dakwaan alternatif sebagaimana dijelaskan dalam kasus posisi. Majelis Hakim berdasarkan Putusan Pengadilan memilih dakwaan yang dianggap paling tepat sesuai dengan fakta-fakta hukum yang terungkap dalam persidangan yaitu dakwaan alternatif kedua melanggar Pasal 378 juncto Pasal 56 ayat 2 KUHP, yang unsur-unsurnya sebagai berikut:

1. Unsur barang siapa;

2. Unsur sengaja;

3. Unsur memberi kesempatan, sarana atau keterangan;

4. Unsur dengan maksud untuk menguntungkan diri sendiri atau orang lain secara melawan hukum;

5. Unsur dengan memakai nama palsu atau martabat palsu dengan tipu muslihat ataupun rangkaian kebohongan;

6. Unsur menggerakkan orang lain untuk menyerahkan barang sesuatu kepadanya atau supaya memberi hutang atau menghapuskan piutang.

Notaris berdasarkan Putusan Pengadilan tersebut telah memenuhi unsur-unsur tersebut.

Bahwa terkait pemenuhan unsur-unsur tersebut di atas, pertimbangan hakim dalam Putusan Pengadilan tersebut adalah:

1. Unsur barang siapa

Bahwa unsur barang siapa adalah siapa saja sebagai subyek hukum yang mampu dimintai pertanggungjawabannya terhadap tindak pidana yang dilakukan olehnya. Memang pandangan klasik berpendapat bahwa subyek tindak pidana adalah orang pribadi meskipun ia berkedudukan sebagai pengurus atau komisaris suatu badan hukum. Namun dalam perkembangan zaman subyek tindak pidana diperluas termasuk badan hukum. Salah satu unsur obyektif tindak pidana adalah kualitas dari si pelaku, yang dalam hal ini Penuntut umum mengajukan Terdakwa I Ketut Neli Asih, SH yang dalam hal ini berkedudukan dalam jabatannya selaku Notaris di Kabupaten Badung.

${ }^{51}$ Musri Nauli, "Unsur "Barang Siapa" Dalam Tindak Pidana", diakses dari http://musrinauli.blogspot.com/2012/07/unsur-barang-siapa-dalam-tindak-pidana.html, pada tanggal 5 Agustus 2020 pukul 15.12.

${ }^{52}$ Heriyanti, Op.Cit., hlm. 211. 
2. Unsur sengaja

Kesengajaan adalah adanya sifat "Wellen and Wetten" atau sifat mengetahui dan menghendari dari Terdakwa, yang mana terdapat 3 jenis perbuatan sengaja, yaitu:

- Sengaja sebagai niat (Oogmerk), bahwa dengan kesengajaan yang bersifat tujuan perbuatan si pelaku dapat dipertanggungjawabkan, bahwa dengan adanya kesengajaan yang bersifat tujuan ini, dapat dikatakan si pelaku benar-benar menghendaki mencapai akibat yang menjadi pokok alasan perbuatan.

- Sengaja sadar akan kepastian atau keharusan (Zekerheidsbewustzijn), bahwa pelaku dengan perbuatannya tidak bertujuan untuk mencapai akibat yang menjadi dasar dan delik tetapi ia tahu benar bahwa akibat tersebut pasti akan mengikuti perbuatannya.

- Sengaja sadar akan kemungkinan (Dolus eventualis, Mogeliikeheidsbewustzjin), bahwa terwujudnya delik bukan merupakan tujuan dari pelaku, melainkan merupakan syarat yang mungkin timbul sebelum/pada saat/sesudah/ tujuan pelaku tercapai.

Bahwa berdasarkan fakta hukum pada tanggal 8 Agustus 2014, Terdakwa menerima dokumen-dokumen sebagai dasar pembuatan Akta Kuasa Menjual, antara lain adalah perjanjian pengikatan jual beli nomor 30 dan akta kuasa menjual nomor 31, keduanya tertanggal 20 November 2012, yang dibuat di hadapan Putu Trisna Rosilawati, SH, Notaris di Kabupaten Badung, yang menurut keterangan dari saksi Putu Trisna Rosilawati, SH, dalam persidangan kedua akta tersebut sudah dibuatkan akta pembatalan dan pencabutan kuasa sebagaimana ternyata dalam akta pembatalan nomor 5 dan akta pencabutan kuasa nomor 6, keduanya tertanggal 4 Juli 2014. Bahwa Terdakwa tidak menerapkan prinsip kehati-hatian dengan tidak melakukan konfirmasi pengecekan atas dokumen tersebut, yang sepatutnya Terdakwa memiliki kesadaran akan kemungkinan tidak berlakunya perjanjian pengikatan jual beli dan akta kuasa menjual tersebut.

Bahwa pada saat penandatanganan Akta Kuasa Menjual, Terdakwa tidak menceritakan kepada saksi (korban) terkait posisi asli SHGB Nomor 7062 yang sudah tidak pada Terdakwa, yang mana sertipikat tersebut sudah diambil oleh saksi Sugihartini pada tanggal 13 Agustus 2014 atas perintah dari saksi Gunawan Priambodo. Dalam hal ini Terdakwa sadar bahwa apabila tetap melanjutkan pembuatan Akta Kuasa Menjual hanya dengan fotokopi SHGB Nomor 7062 (asli SHGB tersebut berada di kantor saksi Triska Damayanti), maka bisa di kemudian hari akan timbul akibat yang tidak diinginkan, karena tidak ada jaminan dari pihak siapapun bahwa SHGB Nomor 7062 benar dilakukan pemecahan dan balik nama dalam waktu 3 bulan, dengan mendasar pada prinsip kehati-hatian dan memperjelas dokumen-dokumen yang diajukan dalam pembuatan Akta Kuasa Menjual, seyogyanya Terdakwa menolak apabila tidak ada atau tidak ditunjukkan asli SHGB Nomor 7062 .

3. Unsur memberi kesempatan, sarana atau keterangan

Bahwa pembantuan (medeplichtige) diklasifikasikan menjadi pembantuan pada saat kejahatan dilakukan (mirip dengan medeplegen (turut serta)) dan pembantuan sebelum kejahatan dilakukan yaitu dengan cara memberi kesempatan, sarana, keterangan (mirip dengan penganjuran (uitlokking)). Berkaitan dengan kasus sudah diuraikan pada pembahasan point 2.

4. Unsur dengan maksud untuk menguntungkan diri sendiri atau orang lain secara melawan hukum. 
Bahwa melawan hukum adalah suatu tindakan yang tidak sesuai dengan hukum. Istilah "unsur melawan hukum pidana (wederrechtelijk)" menurut Prof. Moeljatno yang merupakan syarat mutlak bagi terjadinya suatu perbuatan pidana adalah:

- Bertentangan dengan hak subyektif orang lain;

- Bertentangan dengan kewajiban hukum orang yang berbuat;

- Bertentangan dengan kesusilaan.

Bahwa dalam kasus tersebut sebelumnya saksi Gunawan Priambodo memiliki kewajiban mengembalikan uang milik saksi (korban) berupa piutang yang timbul akibat kegagalan dalam beberapa transaksi di masa lalu, sehingga menguntungkan diri sendiri dan mengindari kewajiban pengembalian uang/piutang tersebut. Saksi Gunawan Priambodo menawarkan kepada saksi (korban) untuk menjadikan piutang sebagai sarana pelunasan terhadap sisa pembayaran tanah Paradise Loft. Cara pelunasan pembayaran tersebut adalah secara melawan hukum.

Bahwa saksi Gunawan Priambodo pada tanggal 4 Juli 2014 di kantor Notaris Putu Trisna Rosilawati, SH, membuat akta pembatalan tanggal 4 Juli 2014 Nomor 5 dan akta pencabutan kuasa tanggal 4 Juli 2014 Nomor 6 terhadap akta Perjanjian Pengikatan Jual Beli tanggal 20 November 2012 Nomor 30 terkait jual beli tanah Paradise Loft, namun pada saat penandatanganan akta pembatalan dan pencabutan kuasa tersebut saksi Gunawan Priambodo tidak menyerahkan kembali salinan PPJB kepada Notaris Putu Trisna Rosilawati, SH serta pada saat melakukan transaksi pelunasan pembayaran dengan saksi (korban) tetap menjadikan PPJB tersebut sebagai alas hak dalam transaksi tanah Paradise Loft di kantor Notaris Terdakwa.

5. Unsur dengan memakai nama palsu atau martabat palsu, dengan tipu muslihat atau rangkaian kebohongan.

Bahwa pada tanggal 4 September 2014 di kantor terdakwa, saksi Gunawan Priambodo pada saat pembuatan Akta Kuasa Menjual mengatakan kepada saksi (korban) bahwa SHGB Nomor 7062 masih dalam proses pemecahan, namun pada kenyataannya SHGB tersebut berada di kantor Notaris Triska Damayanti dalam rangka transaksi dengan pihak lain, bukan pemecahan sebagaimana dikatakan oleh Terdakwa kepada saksi (korban), kemudian tetap menggunakan PPJB dan kuasa tersebut sebagai alas hak pembuatan Akta Kuasa Menjual yang dijadikan suatu bentuk pelunasan terhadap pembelian tanah Paradise Loft, yang kenyataannya alas hak tersebut sudah tidak berlaku, karena sudah dilakukan pembatalan dan pencabutan kuasa.

6. Unsur menggerakkan orang lain untuk menyerahkan barang sesuati kepadanya, atau supaya memberi hutang maupun menghapuskan piutang.

Bahwa saksi (korban) bersedia untuk membuat Akta Kuasa Menjual sebagai tanda pelunasan pembayaran tanah Paradise Loft, kemudian pada saat pembuatan Akta Kuasa Menjual tersebut terdapat isi dari akta yang mengatur tentang pembayaran terhadap pembelian tanah Paradise Loft telah lunas. Bahwa pelunasan yang dimaksud berdasarkan penawaran saksi Gunawan Priambodo kepada saksi (korban) yang akhirnya menjadi kesepakatan berupa "penghapusan kewajiban pengembalian sejumlah uang/piutang" milik saksi (korban) yang masih ada pada saksi Gunawan Priambodo. Bahwa dengan dibuatnya Akta Kuasa Menjual tersebut mengakibatkan saksi (korban) percaya serta tergerak hatinya untuk menghapuskan piutang miliknya yang masih ada pada saksi 
Gunawan Priambodo oleh karena telah dijadikan alat pelunasan pembayaran sebagaimana telah tertuang dalam Akta Kuasa Menjual pada kantor Terdakwa.

Berdasarkan pertimbangan Hakim tersebut dalam Putusan Pengadilan, Terdakwa telah memenuhi unsur-unsur dakwaan alternatif kedua penuntut umum yaitu Pasal 378 juncto Pasal 56 ayat 2 KUHP dan memutuskan Terdakwa terbukti secara sah dan meyakinkan bersalah melakukan tindak pidana "sengaja memberi kesempatan atau sarana dalam tindak pidana penipuan" berupa produk Akta Kuasa Menjual yang dibuat di hadapannya. Berdasarkan Putusan Putusan Pengadilan Negeri Nomor 196/Pid.B/2019/PN Dps, Notaris dijatuhi pidana penjara selama 1 (satu) tahun dan 4 (empat) bulan, yang kemudian diajukan banding dan berdasarkan pertimbangan hakim dalam Putusan Pengadilan Tinggi Nomor 27/Pid/2019/PT DPS menyatakan bahwa pertimbangan dan putusan Pengadilan Negeri Nomor 196/Pid.B/2019/PN Dps tanggal 25 April 2019 berkaitan dengan terbuktinya tindak pidana yang dilakukan oleh Terdakwa sudah tepat dan benar dan Terdakwa tetap ditanyakan bersalah, dengan mempertimbangkan masa kerja Terdakwa sebagai pejabat umum yang berwenang membuat akta otentik berdasarkan UUJN dalam memberikan pelayanan kepada masyarakat sudah 11 (sebelas) tahun yang dengan ini dapat dipergunakan sebagai alasan untuk meringankan hukuman yang dijatuhkan kepada Terdakwa dan Hakim menjatuhkan pidana penjara selama 1 (satu) tahun dan 2 (dua) bulan dan menguatkan putusan Putusan Pengadilan Negeri Denpasar Nomor 196//Pid.B/2019/PN Dps tanggal 25 April 2019 untuk selebihnya.

Bahwa selain sanksi pidana, Notaris juga dapat dikenakan sanksi administrasi. Berdasarkan Pasal 85 UUJN, jenis sanksi yang dapat dijatuhkan kepada Notaris adalah:

1. teguran lisan;

2. teguran tertulis;

3. pemberhentian sementara;

4. pemberhentian dengan hormat;

5. pemberhentian tidak hormat.

Dalam pelaksanaan sanksi pada Pasal 85 UUJN dilakukan secara berjenjang. Sebelum dijatuhkan sanksi Notaris harus didahului dengan teguran lisan dan teguran tertulis yang tujuannya adalah untuk menguji ketepatan dan kecermatan (akurasi) antar teguran lisan dan tertulis dengan pelanggaran yang dilakukan berdasarkan aturan hukum yang berlaku serta memberikan hak kepada Notaris untuk membela diri dalam suatu upaya administrasi dalam bentuk keberatan atau banding administrasi. Ketentuan tersebut berkaitan dengan Pasal 3 ayat (2) dan ayat (3) Peraturan Menteri Hukum dan Hak Asasi Manusia Republik Indonesia Nomor 61 Tahun 2016 tentang Tata Cara Penjatuhan Sanksi Administratif Terhadap Notaris, yang menyatakan bahwa penjatuhan sanksi administratif dilakukan secara berjenjang mulai dari sanksi teguran sampai sanksi terberat sesuai dengan tata urutan sebagaimana dimaksud pada ayat (1) dan dalam hal tertentu Notaris yang melakukan pelanggaran yang berat terhadap kewajiban dan larangan jabatan dapat langsung dijatuhi sanksi administratif tanpa dilakukan secara berjenjang.

Sanksi pemberhentian sementara dari jabatan merupakan tahap berikutnya setelah penjatuhan sanksi teguran lisan dan tertulis. Kedudukan sanksi pemberhentian sementara merupakan masa menunggu pelaksanaan sanksi paksaan pemerintah. Sanksi tersebut dapat berakhir dalam bentuk pemulihan kepada Notaris untuk menjalankan tugas jabatannya kembali atau ditindaklanjuti dengan sanksi pemberhentian dengan hormat atau pemberhentian tidak hormat. Berdasarkan Pasal 9 ayat (1) UUJN menyatakan bahwa notaris diberhentikan sementara dari jabatan karena:

1. dalam proses pailit atau penundaan kewajiban pembayaran utang;

2. berada di bawah pengampuan;

3. melakukan perbuatan tercela; atau 
4. melakukan pelanggaran terhadap kewajiban dan larangan jabatan.

Terkait kasus tersebut, bahwa pada tanggal 20 Maret 2019 dilakukan pemeriksaan protokol Terdakwa oleh Majelis Pengawas Daerah Notaris, sebagaimana ternyata dalam Pemeriksaaan Protokol Notaris Nomor : 01/BAP/MPDN Kab Badung/III/2019 TAHUN 2019, dalam pemeriksaan tersebut tidak bertemu dengan Terdakwa dikarenakan Terdakwa sedang menjalani penahanan pada Kejaksaan Negeri Denpasar. Bahwa Majelis Pengawas Pusat juga telah memanggil Terdakwa melalui surat Nomor UM.MPPN.07.19-57 tanggal 3 Juli 2019, Notaris tidak hadir karena sedang menjalankan pidana penjara.

Bahwa dengan adanya Putusan Pengadilan Negeri Nomor 196/Pid.B/2019/PN Dps tanggal 25 April 2019 dan Putusan Pengadilan Tinggi Nomor 27/Pid/2019/PT DPS pada tanggal 29 Juli 2019 serta pertimbangan dalam rapat musyawarah Majelis Pengawas Pusat, Majelis Pengawas Pusat Notaris pada tanggal 23 Juli 2019 mengeluarkan Putusan Nomor 16/B/MPPN/VI/2019, yang memutuskan sebagai berikut:

1. Menyatakan bahwa Ketut Neli Asih, SH Notaris Kabupaten Badung tidak berwenang untuk menjalankan jabatannya sebagai Notaris selama menjalani masa tahanan;

2. Menjatuhkan sanksi pemberhentian sementara selama 6 (enam) bulan kepada Ketut Neli Asih, SH Notaris Kabupaten Badung, karena terbukti bersalah melakukan tindak pidana berdasarkan Putusan Pengadilan Negeri Denpasar Nomor 196/Pid.B/2019/PN Dps tanggal 25 April 2019, yang berlaku efektif setelah Ketut Neli Asih, SH, selesai menjalankan hukuman pidananya;

3. Memerintahkan Majelis Pengawas Daerah Notaris Kabupaten Badung untuk menunjuk Notaris pemegang protokol atas Notaris Ketut Neli Asih, $\mathrm{SH}$;

4. Memerintahkan Ketut Neli Asih, SH Notaris Kabupaten Badung untuk melakukan serah terima protokol notaris yang berada dalam penguasaannya kepada Notaris Pemegang Protokol dalam jangka waktu 30 (tiga puluh) hari sejak Surat Keputusan Pemberhentian diterbitkan.

Bahwa upaya hukum kasasi terhadap Putusan Pengadilan Negeri Nomor 196/Pid.B/2019/PN Dps tanggal 25 April 2019 dan Putusan Pengadilan Tinggi Nomor 27/Pid/2019/PT DPS pada tanggal 29 Juli 2019, batas waktu pemberitahuannya sudah habis. Penasihat hukum Terdakwa melakukan upaya hukum luar biasa dengan mengajukan permohonan Peninjauan Kembali terhadap putusan pengadilan tinggi pada tanggal 13 November 2019, dan pada tanggal 14 Mei 2020, permohonan peninjauan Kembali Terdakwa tersebut dikabulkan oleh Mahkamah Agung Republik Indonesia sebagaimana ternyata dalam Petikan Putusan Nomor 20 PK/Pid/2020 yang menyatakan mengabulkan permohonan peninjauan Kembali dari Terdakwa dan membatalkan putusan Pengadilan Tinggi Denpasar Nomor 27/Pid/2019/PT DPS tanggal 27 Juni 2019 dan memutuskan sebagai berikut:

1. Menyatakan terpidana Ketut Neli Asih, SH terbukti melakukan perbuatan sebagaimana didakwakan kepadanya, akan tetapi perbuatan itu tidak merupakan suatu tindak pidana;

2. Melepaskan terpidana tersebut oleh karena itu dari segala tuntuan hukum (onstlag van alle rechtsvervolging);

3. Memulihkan hak terpidana dalam kemampuan, kedudukan dan harkat serta martabatnya;

4. Menetapkan barang bukti dipergunakan dalam pembuktian perkara atas nama terdakwa Gunawan Priambodo;

5. Membebankan biaya perkara pada pemeriksaan Peninjauan Kembali kepada Negara. 
Dalam putusan Peninjuan Kembali tersebut tidak disebutkan mengenai pertimbangan hakim dalam pengambilan putusan, sehingga penulis tidak membahas lebih lanjut putusan tersebut.

Dari uraian tersebut di atas, bahwa pertanggungjawaban Notaris terhadap Akta Kuasa Menjual yang memenuhi unsur memberi kesempatan atau sarana dalam tindak pidana penipuan adalah pemberian sanksi pidana sesuai ketentuan KUHP berdasarkan Putusan Pengadilan Negeri Nomor 196/Pid.B/2019/PN Dps tanggal 25 April 2019 yaitu menjatuhkan pidana kepada Terdakwa dengan pidana penjara selama 1 (satu) tahun dan 4 (empat) bulan dan berdasarkan Putusan Pengadilan Tinggi Denpasar Nomor 27/Pid/2019/PT DPS tanggal 27 Juni 2019 menjatuhkan pidana kepada Terdakwa dengan pidana penjara selama: 1 (satu) tahun dan 2 (dua) bulan. Berdasarkan Putusan Pidana tersebut dan pertimbangan dalam rapat musyawarah Majelis Pengawas Pusat, Majelis Pengawas Pusat Notaris pada tanggal 23 Juli 2019 mengeluarkan Putusan Nomor 16/B/MPPN/VI/2019 yaitu pemberian sanksi administratif berupa sanksi pemberhentian sementara selama 6 (enam) bulan. Sanksi keperdataan terhadap Akta Kuasa Menjual tersebut, pihak yang dirugikan sebagai akibat langsung dari suatu akta dapat menuntut secara perdata terhadap Notaris berupa ganti rugi. Apabila putusan pengadilan tidak berkeadilan bagi Notaris, Notaris dapat melakukan upaya hukum luar biasa berupa peninjauan kembali kepada Mahkamah Agung terhadap putusan pengadilan yang telah berkekuatan hukum tetap untuk mendapatkan keadilan yang diharapkan sehingga dapat memulihkan nama baik Notaris.

\section{KESIMPULAN}

1. Bahwa Akta Kuasa Menjual yang dibuat oleh Notaris yang memenuhi unsur sengaja memberi kesempatan atau sarana dalam tindak pidana penipuan dalam Putusan Pengadilan Negeri Nomor 196/Pid.B/2019/PN Dps juncto Putusan Pengadilan Tinggi Denpasar Nomor 27/Pid/2019/PT DPS adalah kuasa yang berdiri sendiri, yang sebelumnya tidak ada perjanjian pokok yaitu perjanjian pengikatan jual beli. Bahwa Akta Kuasa Menjual tersebut memuat klausul jual beli pada premis akta dan merupakan kuasa mutlak yaitu kuasa yang didalamnya mengandung unsur tidak dapat ditarik kembali oleh pemberi kuasa dan pada hakekatnya merupakan pemindahan hak atas tanah yang dilarang berdasarkan Pasal 39 ayat (1) huruf (d) Peraturan Pemerintah Nomor 24 Tahun 1997, sehingga dapat beresiko batal demi hukum. Untuk menentukan akibat hukum Akta Kuasa Menjual harus diajukan terlebih dahulu dalam sidang pengadilan oleh pihak yang merasa dirugikan sampai mendapatkan putusan pengadilan yang berkekuatan hukum tetap mengenai akibat batal demi hukum tersebut.

2. Bahwa pertanggungjawaban Notaris terhadap Akta Kuasa Menjual tersebut adalah pemberian sanksi pidana sesuai ketentuan KUHP berdasarkan Putusan Pengadilan Negeri Nomor 196/Pid.B/2019/PN Dps tanggal 25 April 2019 yaitu menjatuhkan pidana kepada Terdakwa dengan pidana penjara selama 1 (satu) tahun dan 4 (empat) bulan dan dikuatkan dengan Putusan Pengadilan Tinggi Denpasar Nomor 27/Pid/2019/PT DPS tanggal 27 Juni 2019 menjatuhkan pidana penjara selama 1 (satu) tahun dan 2 (dua) bulan. Berdasarkan Putusan Pidana tersebut Majelis Pengawas Pusat Majelis Pengawas Pusat Notaris pada tanggal 23 Juli 2019 mengeluarkan Putusan Nomor 16/B/MPPN/VI/2019 yaitu pemberian sanksi administratif berupa sanksi pemberhentian sementara selama 6 (enam) bulan. 


\section{DAFTAR PUSTAKA}

\section{Perundang-undangan}

Indonesia, Undang-Undang Republik Indonesia tentang Perubahan Atas Undang-Undang Nomor 30 Tahun 2004 tentang Jabatan Notaris, UU No. 2 LN Tahun 2014 No. 3, TLN No. 5491.

, Peraturan Pemerintah Republik Indonesia tentang Pendaftaran Tanah, PP No. 24 Tahun 1997, TLN No. 3696.

Kitab Undang-Undang Hukum Perdata (Burgerlijk Wetboek), Diterjemahkan oleh R. Subekti dan R. Tjitrosudibio, Cet. 34, (Jakarta: Pradya Paramita, 2006), Pasal 1457.

\section{Buku}

Abdulkarim, Aim, Pendidikan Kewarganegaraan, Bandung, Grafindo Media Pratama, 2006.

Adjie, Habib, Hukum Notaris Indonesia Tafsir Tematik Terhadap UU Nomor 2 Tahun 2014 Tentang Perubahan Atas Undang-Undang Nomor 30 Tahun 2004 Tentang Jabatan Notaris, Surabaya, PT. Refika Aditama, 2015. , Meneropong Khasanah Notaris dan PPAT Indonesia (Kumpulan Notaris

dan PPAT), (Bandung: P.T Citra Aditya Bakti, 2009 ),

Ahmadi, Wiratni dkk., Teknik Pembuatan Akta Notaris, Bandung, Logoz Publishing, 2016.

Budiono, Herlin, Ajaran Umum Hukum Perjanjian dan Penerapannya di Bidang Kenotariatan, Bandung, PT. Citra Aditya Bakti, 2019. , Kumpulan Tulisan Hukum Perdata di Bidang Kenotariatan, (Bandung: Citra Aditya Bandung, 2007),

Hieariej, Eddy O.S., Prinsip-Prinsip Hukum Pidana, Yogyakarta, Cahaya Atma Pustaka, 2016.

Irsan, Koesparmono dan Armansyah, Panduan Memahami Hukum Pembuktian Dalam Hukum Perdata dan Hukum Pidana, Jakarta, Gramata Publishing, 2016.

Mamuji, Sri, Et al, Metode Penelitian dan Penulisan Hukum, Jakarta, Badan Penerbit Hukum Universitas Indonesia, 2005.

Panjaitan, Hulman, Kumpulan Kaidah Hukum Putusan Mahkamah Agung Republik Indonesia Tahun 1953 s/d 2008 Berdasarkan Penggolongannya, (Jakarta: Kencana, 2014),

Perangin, Effendi, Hukum Agraria Indonesia Suatu Telaah Dari Sudut Pandang Praktisi Hukum, Jakarta, PT. Raja Grafindo Persada, 1994.

Salim, Hukum Kontrak Teori \& Teknik Penyusunan Kontrak, Jakarta, Sinar Grafika, 2015.

Sjaifurrachman dan Habib Adjie, Aspek Pertanggungjawaban Notaris dalam Pembuatan Akta, Bandung, Mandar Maju, 2011.

Soekanto, Soerjono, Pengantar Penelitian Hukum, cet.3, Jakarta, UI-Press, 1986.

Subekti, R., Hukum Perjanjian, Jakarta, Internasa, 1979.

Sutedi, Adrian, Peralihan Hak Atas Tanah dan Pendaftarannya, Jakarta, Sinar Grafika, 2007. 


\section{Internet}

Darussalam, Retno S., "Surat Kuasa Penjualan", diakses dari https://www.hukumonline.com/klinik/detail/ulasan/lt4ca331071728a/surat-kuasapenjualan/, diakses pada tanggal 18 Maret 2020.

Literasi publik, "Pemahaman Manusia Sebagai Makhluk Sosial", diakses dari https://www.literasipublik.com/pemahaman-manusia-sebagai-makhluk-sosial, diakses pada tanggal 12 Maret 2020

Nauli, Musri, "Unsur "Barang Siapa" Dalam Tindak Pidana", diakses dari http://musrinauli.blogspot.com/2012/07/unsur-barang-siapa-dalam-tindak-pidana.html, diakses pada tanggal 5 Agustus 2020.

Simamora, Bhakti, "Akta Kuasa Menjual Tanah/Bangunan", diakses dari http://notaris-bhakti-simamora.blogspot.com/2017/03/akta-kuasa-menjual-tanahdan-bangunan.html, diakses pada tanggal 3 Maret 2020.

\section{Jurnal}

Andhika, Ahmad Reza, "Pertanggungjawaban Notaris Dalam Perkara Pidana Berkaitan Dengan Akta Yang Dibuatnya Menurut Undang-Undang Nomor 30 Tahun 2004", Premis Law Jurnal, 2016.

Fatmawati, "Kajian Yuridis Pembatalan Perjanjian Pengikatan Akta Jual Beli Tanah Terkait Syarat Subjektif", Jurnal Magister Kenotariatan Fakultas Hukum Universitas Negeri Sebelas Maret Vol 6 No. 1, 2019.

Kurniawati, Leny, "Akta Perjanjian Pengikatan Jual Beli Dan Kuasa Menjual Sebagai Bentuk Perlindungan Hukum Terhadap Pembeli Hak Atas Tanah", Jurnal Hukum dan Kenotariatan Volume 2 Nomor 1 Februari 2018.

Pradita, Nur Dwitya, "Perbuatan Notaris Yang Melakukan Peralihan Hak Atas Tanah Menggunakan Kuasa Jual Yang Perjanjian Pengikatan Jual Belinya Belum Lunas (Studi Kasus Putusan Pengadilan Negeri Nomor 120/PDT.G/2018/PN.TGN Dan Putusan Majelis Pemeriksa Pusat Notaris Nomor 08/B/MPPN/XI/2018)", Jurnal Universitas Indonesia, 2019.

Reswari, Gedion Ardana, "Surat Kuasa Mutlak Pada Perjanjian Pengikatan Jual Beli Hak Atas Tanah”, Jurnal Rechtens, Vol.3, No. 1, 2014.

Setiawan, I Ketut Oka, "Lembaga Kuasa dan Kuasa Mutlak", Jurnal Judical Volume III Nomor 2, 2008.

Vania, Clara dan Gunawan Djajaputra, "Keabsahan Penggunaan Kuasa Mutlak Dalam Perjanjian Pengikatan Jual Beli (PPJB) Tanah Yang Dibuat Oleh Notaris". Jurnal Hukum Adigama, 2018.

Wiradireja, Hilda Sophia, "Pertanggungjawaban Pidana Notaris Dalam Pembuatan Akta Yang Didasarkan Pada Keterangan Palsu Dihubungkan Dengan UndangUndang Nomor 30 Tahun 2004 Tentang Jabatan Notaris Jo Undang-Undang Nomor 2 Tahun 2014 dan KUHP”, Jurnal Wawasan Hukum, 2015. 